\title{
The glacial history of the Dinaric Alps, Montenegro
}

\author{
P.D. Hughes ${ }^{\mathrm{a}, *}$, J.C. Woodward ${ }^{\mathrm{a}}$, P.C. van Calsteren ${ }^{\mathrm{b}}$, L.E. Thomas ${ }^{\mathrm{b}}$ \\ ${ }^{a}$ Quaternary Environments and Geoarchaeology Research Group, Geography, School of Environment and Development, The University of Manchester, Manchester M13 9PL, UK \\ ${ }^{\mathrm{b}}$ Natural Environment Research Council - Open University Uranium-Series Facility, Department of Earth and Environmental Sciences, The Open University, \\ Milton Keynes MK7 6AA, UK
}

\section{A R T I C L E I N F O}

\section{Article history:}

Received 1 May 2011

Received in revised form

17 August 2011

Accepted 29 August 2011

Available online 4 October 2011

\section{Keywords:}

Glaciation

Balkans

Pleistocene

Former Yugoslavia

Palaeoclimate

Refugia

\begin{abstract}
A B S T R A C T
Large areas of Montenegro were glaciated during the Pleistocene. This paper presents evidence from the massifs of central Montenegro, including Durmitor and Sinjajevina, Moračke Planine, Maganik, Prekornica and Vojnik. Glacial deposits have been subdivided on the basis of morphostratigraphy and soil weathering and $31 \mathrm{U}$-series ages from cemented tills provided a geochronological framework. The largest glaciation occurred before 350 ka when a series of conjoined ice caps over the massifs of central Montenegro covered a total area of nearly $1500 \mathrm{~km}^{2}$. These formed during MIS 12 and correspond with the largest Skamnellian Stage glaciations in Greece to the south. Later Middle Pleistocene glaciations occurred during the penultimate glacial cycle correlating with the Vlasian Stage in Greece (MIS 6) when ice caps covered an area of $720 \mathrm{~km}^{2}$ over central Montenegro. There is also geochronological evidence of glacial deposits dating from the interval between MIS 12 and MIS 6, before the interglacial complex of MIS 7. This glaciation appears to have been very similar in extent to that which occurred during MIS 6. The last glacial cycle in central Montenegro was characterised by valley and cirque glaciers covering a total area of $49 \mathrm{~km}^{2}$. It is very likely that glaciers have been present in the mountains of central Montenegro during every glacial cycle since a small glacier still survives today. The smaller glaciers of the last glacial cycle are likely to have been associated with summer temperatures that were warmer than those of earlier cold stages. The striking contrast in the extent and thickness of ice cover during the cold stages of the Pleistocene has an important bearing on the geomorphological and biological evolution of the Balkans.
\end{abstract}

(c) 2011 Elsevier Ltd. All rights reserved.

\section{Introduction}

The nature of glaciations in the Mediterranean mountains has been the subject of increasing research in recent years (see reviews in Hughes and Woodward, 2008, 2009). This recent activity builds on a long history of research in the region (see review by Messerli, 1967). Some of the earliest work in southern Europe was carried out in the Dinaric Alps of Montenegro and neighbouring countries, where evidence of widespread glaciation was noted by Jovan Cvijić (Cvijić, 1889) well over a century ago. This was followed by numerous papers on glaciation in the Balkans (see references in Section 4.1). Cvijić (1914) recognised that moraines in Montenegro were of different ages and subdivided glacial deposits into old and young moraines (Altmoränen/Jungmoränen). Whilst several recent studies have elaborated on the geomorphology of the different massifs (e.g. Milivojević, 2004a,b; Milivojević et al., 2008; Djurović,

\footnotetext{
* Corresponding author. Tel.: +441612757876.

E-mail address: philip.hughes@manchester.ac.uk (P.D. Hughes).
}

2009), the extent, timing and palaeoclimatic significance of glaciations remains unclear.

Recent research in the Balkans has focused on establishing the number and extent of glaciations and dating the glacial deposits. Moraines in northern Greece and coastal Montenegro have been dated using U-series techniques by Woodward et al. (2004) and Hughes et al. (2006a, 2010), revealing evidence for glaciation during at least three separate cold stages - the oldest occurring earlier than $350 \mathrm{ka}$. In the mountains of both coastal Montenegro and northwest Greece these glaciations have been correlated with cold stages during MIS 12, 6 and 5d-2. There is also tentative evidence of Younger Dryas glacier advances in both Greece and Montenegro (Hughes et al., 2006b, 2010). Today, in common with other southern European mountains (Grunewald and Scheithauer, 2010), small glaciers still exist in the highest parts of Montenegro and Albania, although these exist well below the regional snowline and survive because of strong local topoclimatic controls (Hughes, 2008, 2009).

On Mount Orjen, in the coastal mountains of Montenegro, a Middle Pleistocene ice cap covered an area of $165 \mathrm{~km}^{2}$ (Hughes et al., 2010). By comparison, on Mount Tymphi (2497 $\mathrm{m}$ a.s.l.) in 
northwestern Greece, ice fields and valley glaciers covered an area of just $60 \mathrm{~km}^{2}$ at their maximum extent (Hughes et al., 2006a, 2007). However, early research by Cvijić $(1913,1917)$ revealed that some of the largest ice masses in the Balkans formed in the mountains of central Montenegro and northern Albania.

Large Pleistocene glaciations have also been reported from Croatia, with Marjanac et al. (1990) and Marjanac and Marjanac (2004) reporting glacial deposits near the Velebit Mountains reaching down to sea level and ascribed to at least the Middle Pleistocene. Throughout the mountains of the Balkans, Late Pleistocene glaciers were largely restricted to cirques and valleys and did not extend beyond the mountain centres to the piedmonts (e.g. Bognar and Prugovečki, 1997; Velić et al., 2011). East of the Dinaric Alps and Pindus Mountains, moraines in the cirques and valleys of the Šara Mountains of Kosovo have been dated to the global last glacial maximum (LGM) and no earlier Pleistocene moraines have been reported (Kuhlemann et al., 2009). The same is true in the mountains of Turkey (e.g. Akçar et al., 2007, 2008; Sarıkaya et al., 2008, 2009; Zahno et al., 2009). However, on Mount Olympus in northeastern Greece the most extensive glacial deposits have been ascribed to the Middle Pleistocene (Smith et al., 1997, 2006) - in common with the records in northwestern Greece, Montenegro and Croatia, as noted above.

This paper focuses on the evidence for the extent, timing and palaeoclimatic significance of glaciations in the mountains of central Montenegro. The principal objectives of this paper are: (1) to present geomorphological evidence for the extent, stratigraphical succession and relative-age of different glaciations; (2) to provide a geochronological framework for glaciations using U-series dating of secondary carbonate cements, and; (3) to reconstruct glaciers of different ages using glaciological models and assess the implications for understanding cold stage palaeoclimates.

\section{Study areas}

The six adjacent massifs of central Montenegro covered in this study (Durmitor, Sinjajevina, Moračke Planine, Maganik, Prekornica and Vojnik) extend over $70 \mathrm{~km}$ from Durmitor in the north to Prekornica in the south (Fig. 1). They form the southern end of the Dinaric Alps, which continue southwards as the Albanian Alps and then the Pindus Mountains of Greece. The mountains of central Montenegro are formed in Triassic limestones and dolomites and Cretaceous limestones and flysch with small outcrops of Triassic intrusive volcanics (Osnovna Geološka Karta SFRJ, 1970, 1971; Živaljević et al., 1981; Mirković and Vujisić, 1989). The area is tectonically-active with significant earthquake activity in Montenegro during the Quaternary (Magaš, 2002). The highest peaks in four of the massifs (Durmitor, Sinjajevina, Moračke Planine, and Maganik) reach over $2000 \mathrm{~m}$ a.s.l. and slightly less in the Prekornica and Vojnik massifs. These mountains provide the upper catchments for some of the main rivers in Montenegro: the Morača, Tara and the Piva. The Morača drains into the Adriatic Sea whilst the Tara and the Piva drain to the Black Sea. At Žabljak (1450 m a.s.l.), in the foothills of the Durmitor massif, the mean annual precipitation is $1494 \mathrm{~mm}$ with a mean annual temperature of $5.1^{\circ} \mathrm{C}$ (Ćurić, 1996; Kern et al., 2007). The annual precipitation in the upper catchments of the massif is estimated to be $2500-3000 \mathrm{~mm}$, according to Bošković and Bajković (2004).

\section{Methods}

\subsection{Geomorphology}

The field areas were explored on foot over a period of c. 20 weeks between 2005 and 2010 and glacial and associated landforms were mapped onto 1:25,000 base maps. Glacial depositional landforms were mapped on the basis of morphostratigraphy incorporating lithological and pedological criteria (cf. Hughes, 2010a). Lithological criteria included sediment properties such as clast characteristics (e.g. size, lithology, shape, roundness, presence or absence of striae), clast fabric, matrix composition (e.g. particle size) and sedimentary structures. At selected section exposures at least 50 clasts were measured and described. Clast fabric data were analysed using the computer software Stereonet. Matrix samples ( $<2 \mathrm{~mm}$ fraction) were analysed using a Malvern Mastersizer. Pedological criteria included the quantification of the degree of development of surface soils using the Harden Profile Development Index (PDI) following methods presented in Harden (1982) and Birkeland (1999).

Stratigraphical units were defined at type areas on Durmitor then applied to all other massifs based on correlation of the properties described above according to the following criteria: (1) morphostratigraphical position; (2) soil weathering, and; (3) Useries ages. This differs from other approaches where stratigraphical units can be defined for each cirque-valley system (e.g. in the Pindus Mountains, Greece; Hughes et al., 2006a).

\subsection{Geochronology}

Secondary carbonates (calcite) cementing the glacial sediments were dated using Uranium-series. In glacial systems, the subglacial transport of carbonate rock debris produces abundant fine reactive particles (rock flour) which are susceptible to dissolution and reprecipitation as secondary carbonates (Fairchild et al., 1994). Secondary carbonates have been successfully utilised by various workers, including Kotarba et al. (2001), Woodward et al. (2004), Hughes et al. (2006a), Dehnert et al. (2010) and Hughes et al. (2010) to provide minimum ages for glacial deposits in the mountains of central and southern Europe. In this study, samples were taken from exposed sections using a hammer and chisel (or in the case of friable sediments, were sampled by using a trowel or by hand). Sample locations were spatially referenced using GPS and these data are given in Table 1. Samples were cleaned, sub-sampled and crushed at the University of Manchester following the methods as described in Hughes et al. (2010). Chemical preparation and isotope measurements were then undertaken at the UK Natural Environment Research Council Uranium-Series Facility at the Open University using standard methods (cf. Edwards et al., 1987; van Calsteren and Schwieters, 1995; for details of procedure see Hughes et al., 2010).

All ages were corrected for the detrital contribution of $U$ and Th to the samples. The detrital contribution used in this study assumes that all ${ }^{232}$ Th measured is of detrital origin, that the detritus is in secular equilibrium, and that the 'clays' extracted to provide a Th/U ratio for the calculation were representative of the likely detrital contamination for all samples. The ${ }^{232} \mathrm{Th} /{ }^{238} \mathrm{U}$ ratio of the detritus in samples from central Montenegro was derived from two sites, one from a moraine matrix at Žabljak on Durmitor and another from a moraine matrix at Kolašin, east of Sinjajevina (Fig. 1, Table 1). These sites are located in catchments typical of central Montenegro. The ${ }^{232} \mathrm{Th} /{ }^{238} \mathrm{U}$ ratio of the detrital samples at both Žabljak and Kolašin were identical at 3.21. This value is higher than that for Orjen on the coast where detrital samples yielded and average ${ }^{232} \mathrm{Th} /{ }^{238} \mathrm{U}$ ratio of 2.47 . The higher value for the glaciated catchments of central Montenegro reflects the greater abundance of non-carbonate rocks (especially flysch and localised volcanic outcrops) and the value of 3.21 is closer to the global mean value for continental crust ( $\mathrm{Th} / \mathrm{U}=3.9-4.3)$. Orjen, in contrast, is almost exclusively dominated by Cretaceous limestones and the lower ${ }^{232} \mathrm{Th} /{ }^{238} \mathrm{U}$ ratio of the detrital samples reflects the lower quantities of non-carbonate minerals. 

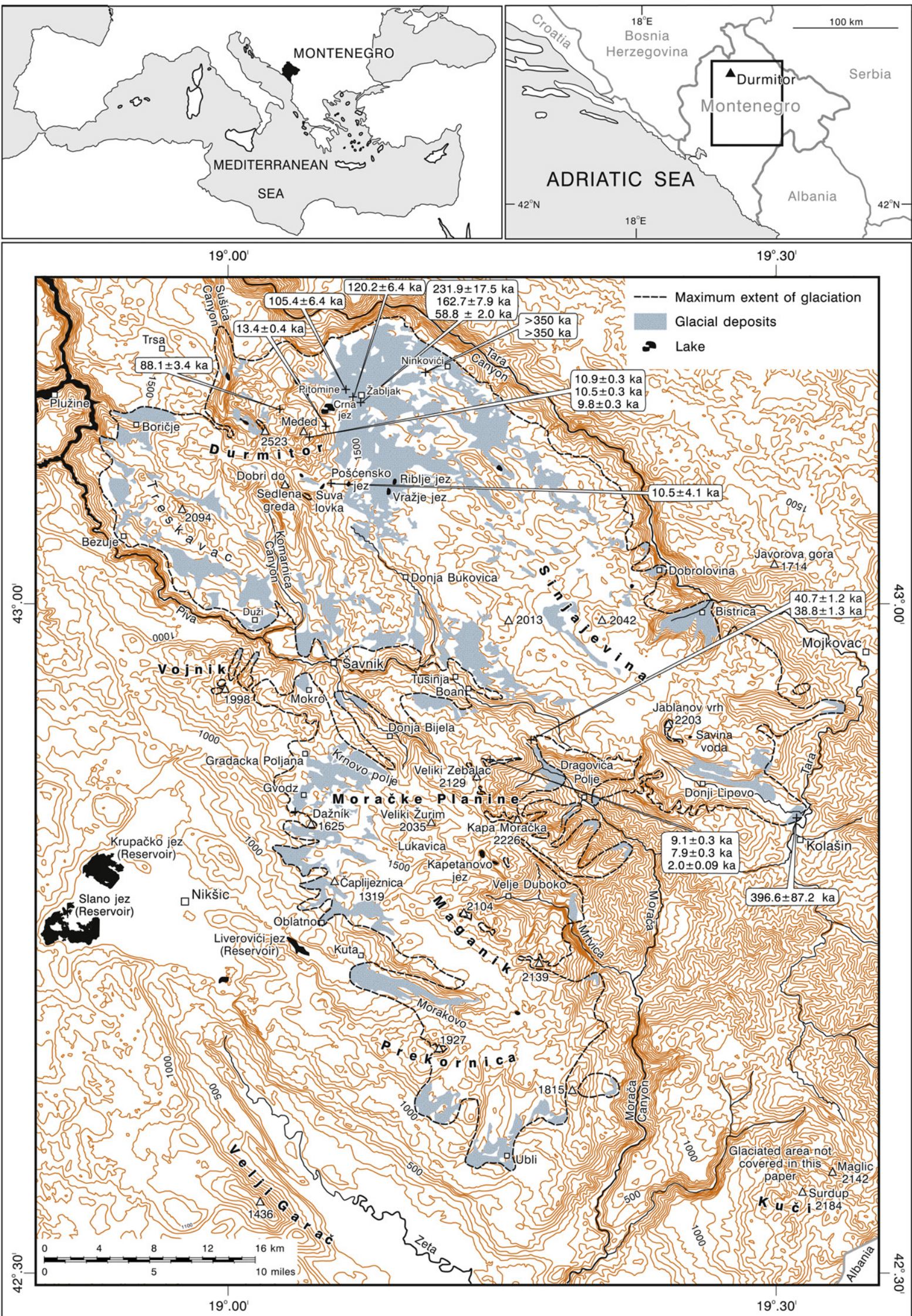

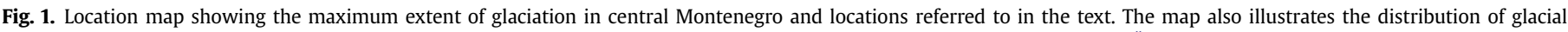

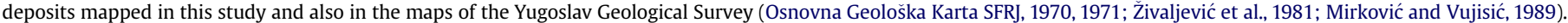

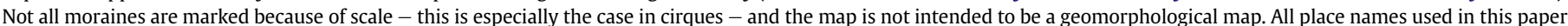
are based on those marked on the military maps (Military Geographical Institute, Belgrade). Abbreviations: jez = jezera (lake). 
Table 1

U-series isotope data from secondary calcites cementing moraines and ${ }^{232} \mathrm{Th} /{ }^{238} \mathrm{U}$ of the detritus at two sites in the central massifs of Montenegro.

\begin{tabular}{|c|c|c|c|c|c|c|c|c|c|c|c|c|c|c|}
\hline Site name & $\begin{array}{l}\text { Lab } \\
\text { code }\end{array}$ & & $\begin{array}{l}{ }^{238} \mathrm{U} \\
\mathrm{ppm}\end{array}$ & $\left({ }^{234} U / /^{238} U\right)$ & ${ }^{234} \mathrm{U} \mathrm{ppm}$ & ${ }^{230} \mathrm{Th} \mathrm{ppb}$ & ${ }^{232} \mathrm{Th} \mathrm{ppb}$ & $\left({ }^{230} \mathrm{Th} /{ }^{232} \mathrm{Th}\right)$ & $\left({ }^{230} \mathrm{Th} /{ }^{234} \mathrm{U}\right)$ & $\left({ }^{234} U /{ }^{238} U\right)$ & $\begin{array}{l}\text { Uncorrected } \\
\text { AGE years }\end{array}$ & $\begin{array}{l}\% \text { err } \\
2 \sigma\end{array}$ & $\begin{array}{l}\text { Corrected AGE } \\
\text { years }\end{array}$ & $\begin{array}{l}\text { \%err } \\
2 \sigma\end{array}$ \\
\hline $\begin{array}{l}\text { Žabljak, Junčev do } \\
43.1509^{\circ} \mathrm{N} \\
19.1269^{\circ} \mathrm{E} \\
1455 \mathrm{~m} \text { a.s.l. }\end{array}$ & M3 & err \pm & $\begin{array}{l}0.018648 \\
0.000188\end{array}$ & $\begin{array}{l}1.257222 \\
0.018007\end{array}$ & $\begin{array}{l}1.265 \mathrm{E}-06 \\
1.294 \mathrm{E}-05\end{array}$ & $\begin{array}{l}0.000313 \\
3.060 \mathrm{E}-06\end{array}$ & $\begin{array}{l}2.619805 \\
0.473571\end{array}$ & $\begin{array}{r}23.5 \\
1.0\end{array}$ & $\begin{array}{l}0.814475 \\
0.008059\end{array}$ & $\begin{array}{l}1.257222 \\
0.018007\end{array}$ & $\begin{array}{l}\mathbf{1 6 6 , 2 3 5} \\
+5509 \\
-5616\end{array}$ & 3.3 & $\begin{array}{l}\mathbf{1 6 2 , 7 0 0} \\
+7673 \\
-7883\end{array}$ & 4.78 \\
\hline $\begin{array}{l}\text { Žabljak, Junčev do } \\
43.1509^{\circ} \mathrm{N} \\
19.1269^{\circ} \mathrm{E} \\
1455 \mathrm{~m} \text { a.s.l. }\end{array}$ & M4 & err \pm & $\begin{array}{l}0.045490 \\
0.000102\end{array}$ & $\begin{array}{l}1.155240 \\
0.004013\end{array}$ & $\begin{array}{l}2.836 \mathrm{E}-06 \\
8.266 \mathrm{E}-09\end{array}$ & $\begin{array}{l}0.000787 \\
6.869 \mathrm{E}-06\end{array}$ & $\begin{array}{l}4.585399 \\
0.828884\end{array}$ & $\begin{array}{r}32.4 \\
1.3\end{array}$ & $\begin{array}{l}0.915023 \\
0.007994\end{array}$ & $\begin{array}{l}1.155240 \\
0.004013\end{array}$ & $\begin{array}{l}\mathbf{2 3 4 , 6 3 1} \\
+11,832 \\
-12,403\end{array}$ & 5.2 & $\begin{array}{l}\mathbf{2 3 1 , 8 8 9} \\
+16,390 \\
-17,504\end{array}$ & 7.31 \\
\hline $\begin{array}{l}\text { Karlica } \\
43.1302^{\circ} \mathrm{N} \\
19.0787^{\circ} \mathrm{E} \\
1890 \mathrm{~m} \text { a.s.l. }\end{array}$ & M5 & err \pm & $\begin{array}{l}0.052565 \\
0.000089\end{array}$ & $\begin{array}{l}1.068404 \\
0.005837\end{array}$ & $\begin{array}{l}3.031 \mathrm{E}-06 \\
1.615 \mathrm{E}-08\end{array}$ & $\begin{array}{l}0.000175 \\
1.623 \mathrm{E}-06\end{array}$ & $\begin{array}{r}18.514026 \\
3.346701\end{array}$ & $\begin{array}{l}1.9 \\
0.1\end{array}$ & $\begin{array}{l}0.190088 \\
0.001770\end{array}$ & $\begin{array}{l}1.068404 \\
0.005837\end{array}$ & $\begin{array}{l}22,970 \\
+466 \\
-467\end{array}$ & 2.0 & $\begin{array}{l}\mathbf{1 0 , 8 5 2} \\
+315 \\
-315\end{array}$ & 2.90 \\
\hline $\begin{array}{l}\text { Žabljak, Junčev do } \\
43.1509^{\circ} \mathrm{N} \\
19.1269^{\circ} \mathrm{E} \\
1455 \mathrm{~m} \text { a.s.l. }\end{array}$ & M6 & err \pm & $\begin{array}{l}0.049960 \\
0.000071\end{array}$ & $\begin{array}{l}1.133596 \\
0.003464\end{array}$ & $\begin{array}{l}3.056 \mathrm{E}-06 \\
9.018 \mathrm{E}-09\end{array}$ & $\begin{array}{l}0.000392 \\
3.630 \mathrm{E}-06\end{array}$ & $\begin{array}{l}0.690405 \\
0.124802\end{array}$ & $\begin{array}{r}109.7 \\
4.6\end{array}$ & $\begin{array}{l}0.422548 \\
0.003919\end{array}$ & $\begin{array}{l}1.133596 \\
0.003464\end{array}$ & $\begin{array}{l}\mathbf{5 9 , 2 1 6} \\
+1404 \\
-1412\end{array}$ & 2.4 & $\begin{array}{l}\mathbf{5 8 , 7 9 9} \\
+1970 \\
-1985\end{array}$ & 3.36 \\
\hline $\begin{array}{l}\text { Karlica } \\
43.1265^{\circ} \mathrm{N} \\
19.0752^{\circ} \mathrm{E} \\
1900 \mathrm{~m} \text { a.s.l. }\end{array}$ & M9 & err \pm & $\begin{array}{l}0.207591 \\
0.000503\end{array}$ & $\begin{array}{l}1.038125 \\
0.005126\end{array}$ & $\begin{array}{l}1.163 \mathrm{E}-05 \\
5.192 \mathrm{E}-08\end{array}$ & $\begin{array}{l}0.000327 \\
2.843 \mathrm{E}-06\end{array}$ & $\begin{array}{l}0.637250 \\
0.115193\end{array}$ & $\begin{array}{r}99.3 \\
4.1\end{array}$ & $\begin{array}{l}0.092599 \\
0.000808\end{array}$ & $\begin{array}{l}1.038125 \\
0.005126\end{array}$ & $\begin{array}{l}\mathbf{1 0 , 6 0 5} \\
+193 \\
-193\end{array}$ & 1.8 & $\begin{array}{l}\mathbf{1 0 , 5 0 2} \\
+270 \\
-270\end{array}$ & 2.57 \\
\hline $\begin{array}{l}\text { Orun katun } \\
43.1339^{\circ} \mathrm{N} \\
19.0946^{\circ} \mathrm{E} \\
1620 \mathrm{~m} \text { a.s.l. }\end{array}$ & M11 & err \pm & $\begin{array}{l}0.141377 \\
0.000221\end{array}$ & $\begin{array}{l}1.028713 \\
0.004349\end{array}$ & $\begin{array}{l}7.848 \mathrm{E}-06 \\
3.221 \mathrm{E}-08\end{array}$ & $\begin{array}{l}0.000280 \\
2.650 \mathrm{E}-06\end{array}$ & $\begin{array}{l}1.188513 \\
0.214842\end{array}$ & $\begin{array}{r}48.9 \\
2.1\end{array}$ & $\begin{array}{l}0.117772 \\
0.001115\end{array}$ & $\begin{array}{l}1.028713 \\
0.004349\end{array}$ & $\begin{array}{l}13,675 \\
+273 \\
-274\end{array}$ & 2.0 & $\begin{array}{l}\mathbf{1 3 , 3 9 0} \\
+378 \\
-379\end{array}$ & 2.83 \\
\hline $\begin{array}{l}\text { Kolašin } \\
42.8402^{\circ} \mathrm{N} \\
19.5235^{\circ} \mathrm{E} \\
940 \mathrm{~m} \text { a.s.l. }\end{array}$ & M12 & err \pm & $\begin{array}{l}0.021756 \\
0.000062\end{array}$ & $\begin{array}{l}1.062030 \\
0.006295\end{array}$ & $\begin{array}{l}1.247 \mathrm{E}-06 \\
6.661 \mathrm{E}-09\end{array}$ & $\begin{array}{l}0.000378 \\
3.217 \mathrm{E}-06\end{array}$ & $\begin{array}{r}13.349018 \\
2.413047\end{array}$ & $\begin{array}{l}5.5 \\
0.2\end{array}$ & $\begin{array}{l}0.999183 \\
0.008534\end{array}$ & $\begin{array}{l}1.062030 \\
0.006295\end{array}$ & $\begin{array}{l}\mathbf{4 1 6 , 1 5 7} \\
+51,095 \\
-64,403\end{array}$ & 13.9 & $\begin{array}{l}\mathbf{3 9 6 , 5 8 2} \\
+64,629 \\
-87,233\end{array}$ & 19.15 \\
\hline $\begin{array}{l}\text { Lijevno (Veliki Zebalac) } \\
42.8826^{\circ} \mathrm{N} \\
19.2390^{\circ} \mathrm{E} \\
1860 \mathrm{~m} \text { a.s.l. }\end{array}$ & M13 & err \pm & $\begin{array}{l}0.044730 \\
0.000083\end{array}$ & $\begin{array}{l}1.116951 \\
0.009251\end{array}$ & $\begin{array}{l}2.696 \mathrm{E}-06 \\
2.200 \mathrm{E}-08\end{array}$ & $\begin{array}{l}0.000105 \\
1.052 \mathrm{E}-06\end{array}$ & $\begin{array}{l}8.125729 \\
1.468877\end{array}$ & $\begin{array}{l}2.9 \\
0.1\end{array}$ & $\begin{array}{l}0.127865 \\
0.001295\end{array}$ & $\begin{array}{l}1.116951 \\
0.009251\end{array}$ & $\begin{array}{l}\mathbf{1 4 , 9 0 4} \\
+318 \\
-318\end{array}$ & 2.1 & $\begin{array}{l}\mathbf{9 , 0 9 7} \\
+277 \\
-277\end{array}$ & 3.04 \\
\hline $\begin{array}{l}\text { Pošćenska jezero } \\
43.0909^{\circ} \mathrm{N} \\
19.1006^{\circ} \mathrm{E} \\
1570 \mathrm{~m} \text { a.s.l. }\end{array}$ & M14 & err \pm & $\begin{array}{l}0.027919 \\
0.000040\end{array}$ & $\begin{array}{l}1.127184 \\
0.004088\end{array}$ & $\begin{array}{l}1.698 \mathrm{E}-06 \\
6.014 \mathrm{E}-09\end{array}$ & $\begin{array}{l}0.000321 \\
2.875 \mathrm{E}-06\end{array}$ & $\begin{array}{l}1.499558 \\
0.271069\end{array}$ & $\begin{array}{r}42.3 \\
1.8\end{array}$ & $\begin{array}{l}0.624118 \\
0.005589\end{array}$ & $\begin{array}{l}1.127184 \\
0.004088\end{array}$ & $\begin{array}{l}\mathbf{1 0 4 , 1 3 9} \\
+2887 \\
-2919\end{array}$ & 2.8 & $\begin{array}{l}\mathbf{1 0 2 , 5 2 6} \\
+4015 \\
-4077\end{array}$ & 3.95 \\
\hline $\begin{array}{l}\text { Donja Ališnica, Glava } \\
43.1464^{\circ} \mathrm{N} \\
19.0477^{\circ} \mathrm{E} \\
2125 \mathrm{~m} \text { a.s.l. }\end{array}$ & M17 & err \pm & $\begin{array}{l}0.021261 \\
0.000036\end{array}$ & $\begin{array}{l}1.345349 \\
0.006694\end{array}$ & $\begin{array}{l}1.543 \mathrm{E}-06 \\
7.453 \mathrm{E}-09\end{array}$ & $\begin{array}{l}0.000298 \\
2.571 \mathrm{E}-06\end{array}$ & $\begin{array}{r}13.442610 \\
2.429964\end{array}$ & $\begin{array}{l}4.3 \\
0.2\end{array}$ & $\begin{array}{l}0.637175 \\
0.005506\end{array}$ & $\begin{array}{l}1.345349 \\
0.006694\end{array}$ & $\begin{array}{l}\mathbf{1 0 4 , 4 0 6} \\
+2700 \\
-2726\end{array}$ & 2.6 & $\begin{array}{l}\mathbf{8 8 , 0 5 5} \\
+3312 \\
-3351\end{array}$ & 3.78 \\
\hline $\begin{array}{l}\text { Ljevista, Aluga } \\
42.8857^{\circ} \mathrm{N} \\
19.2867^{\circ} \mathrm{E} \\
1140 \mathrm{~m} \text { a.s.l. }\end{array}$ & M20 & err \pm & $\begin{array}{l}0.027611 \\
0.000060\end{array}$ & $\begin{array}{l}1.132419 \\
0.006191\end{array}$ & $\begin{array}{l}1.687 \mathrm{E}-06 \\
8.690 \mathrm{E}-09\end{array}$ & $\begin{array}{l}0.000201 \\
1.743 \mathrm{E}-06\end{array}$ & $\begin{array}{r}11.380068 \\
2.057127\end{array}$ & $\begin{array}{l}3.4 \\
0.1\end{array}$ & $\begin{array}{l}0.393345 \\
0.003416\end{array}$ & $\begin{array}{l}1.132419 \\
0.006191\end{array}$ & $\begin{array}{r}\mathbf{5 3 , 9 7 4} \\
+1149 \\
-1153\end{array}$ & 2.1 & $\begin{array}{l}\mathbf{4 0 , 7 0 7} \\
+1241 \\
-1246\end{array}$ & 3.06 \\
\hline Karlica & M22 & & 0.049609 & 1.225071 & 3.280E-06 & 0.000093 & 1.515413 & 12.3 & 0.093548 & 1.225071 & 10,694 & & 9825 & \\
\hline
\end{tabular}

Karlica 


\begin{tabular}{|c|c|c|c|c|c|c|c|c|c|c|c|c|c|c|}
\hline $\begin{array}{l}43.1259^{\circ} \mathrm{N} \\
19.0746^{\circ} \mathrm{E} \\
1900 \mathrm{~m} \text { a.s.l. }\end{array}$ & & err \pm & 0.000071 & 0.003328 & $8.502 \mathrm{E}-09$ & 8.617E-07 & 0.273937 & 0.5 & 0.000867 & 0.003328 & $\begin{array}{l}207 \\
-207\end{array}$ & 1.9 & $\begin{array}{l}+269 \\
-269\end{array}$ & 2.74 \\
\hline $\begin{array}{l}\text { Ljevista, Aluga } \\
42.8857^{\circ} \mathrm{N} \\
19.2867^{\circ} \mathrm{E} \\
1140 \mathrm{~m} \text { a.s.l. }\end{array}$ & M23 & err \pm & $\begin{array}{l}0.033581 \\
0.000046\end{array}$ & $\begin{array}{l}1.120508 \\
0.005859\end{array}$ & $\begin{array}{l}2.030 \mathrm{E}-06 \\
1.052 \mathrm{E}-08\end{array}$ & $\begin{array}{l}0.000259 \\
2.304 \mathrm{E}-06\end{array}$ & $\begin{array}{r}20.192639 \\
3.650135\end{array}$ & $\begin{array}{l}2.5 \\
0.1\end{array}$ & $\begin{array}{l}0.421083 \\
0.003752\end{array}$ & $\begin{array}{l}1.120508 \\
0.005859\end{array}$ & $\begin{array}{l}\mathbf{5 9 , 0 1 1} \\
+1319 \\
-1326\end{array}$ & 2.2 & $\begin{array}{l}\mathbf{3 8 , 8 1 7} \\
+1245 \\
-1250\end{array}$ & 3.21 \\
\hline $\begin{array}{l}\text { Žabljak, Pitomine } \\
43.1620^{\circ} \mathrm{N} \\
19.1190^{\circ} \mathrm{E} \\
1470 \mathrm{~m} \text { a.s.l. }\end{array}$ & M24 & err \pm & $\begin{array}{l}0.028334 \\
0.000067\end{array}$ & $\begin{array}{l}1.101881 \\
0.003820\end{array}$ & $\begin{array}{l}1.685 \mathrm{E}-06 \\
4.722 \mathrm{E}-09\end{array}$ & $\begin{array}{l}0.000329 \\
3.486 \mathrm{E}-06\end{array}$ & $\begin{array}{l}4.115647 \\
0.743986\end{array}$ & $\begin{array}{r}17.3 \\
0.7\end{array}$ & $\begin{array}{l}0.643170 \\
0.006827\end{array}$ & $\begin{array}{l}1.101881 \\
0.003820\end{array}$ & $\begin{array}{l}\mathbf{1 0 9 , 9 8 9} \\
+3756 \\
-3812\end{array}$ & 3.4 & $\begin{array}{l}\mathbf{1 0 5 , 4 4 2} \\
+5085 \\
-5188\end{array}$ & 4.87 \\
\hline $\begin{array}{l}\text { Ninkovici, Orujak } \\
43.1705^{\circ} \mathrm{N} \\
19.1731^{\circ} \mathrm{E} \\
1325 \mathrm{~m} \text { a.s.l. }\end{array}$ & M25 & err \pm & $\begin{array}{l}0.055151 \\
0.000119\end{array}$ & $\begin{array}{l}1.036274 \\
0.016917\end{array}$ & $\begin{array}{l}3.084 \mathrm{E}-06 \\
5.004 \mathrm{E}-08\end{array}$ & $\begin{array}{l}0.001048 \\
1.011 \mathrm{E}-05\end{array}$ & $\begin{array}{r}10.986786 \\
1.986038\end{array}$ & $\begin{array}{r}18.8 \\
0.8\end{array}$ & $\begin{array}{l}1.119790 \\
0.011102\end{array}$ & $\begin{array}{l}1.036274 \\
0.016917\end{array}$ & $>350 \mathrm{ka}$ & & $>350 \mathrm{ka}$ & \\
\hline $\begin{array}{l}\text { Žabljak, Crna jezero road } \\
43.1542^{\circ} \mathrm{N} \\
19.1164^{\circ} \mathrm{E} \\
1430 \mathrm{~m} \text { a.s.l. }\end{array}$ & M26 & err \pm & $\begin{array}{l}0.028925 \\
0.000065\end{array}$ & $\begin{array}{l}1.098858 \\
0.003862\end{array}$ & $\begin{array}{l}1.715 \mathrm{E}-06 \\
5.083 \mathrm{E}-09\end{array}$ & $\begin{array}{l}0.000361 \\
3.829 \mathrm{E}-06\end{array}$ & $\begin{array}{l}5.146201 \\
0.930267\end{array}$ & $\begin{array}{r}14.9 \\
0.6\end{array}$ & $\begin{array}{l}0.693773 \\
0.007365\end{array}$ & $\begin{array}{l}1.098858 \\
0.003862\end{array}$ & $\begin{array}{l}\mathbf{1 2 5 , 7 5 0} \\
+4624 \\
-4709\end{array}$ & 3.7 & $\begin{array}{l}\mathbf{1 2 0 , 1 6 3} \\
+6232 \\
-6388\end{array}$ & 5.25 \\
\hline $\begin{array}{l}\text { Lijevno (Veliki Zebalac) } \\
42.8826^{\circ} \mathrm{N} \\
19.2390^{\circ} \mathrm{E} \\
1860 \mathrm{~m} \text { a.s.l. }\end{array}$ & M28 & err \pm & $\begin{array}{l}0.025805 \\
0.000053\end{array}$ & $\begin{array}{l}1.123751 \\
0.003676\end{array}$ & $\begin{array}{l}1.565 \mathrm{E}-06 \\
4.391 \mathrm{E}-09\end{array}$ & $\begin{array}{l}0.000041 \\
6.102 \mathrm{E}-07\end{array}$ & $\begin{array}{l}6.339843 \\
1.146042\end{array}$ & $\begin{array}{l}2.5 \\
0.1\end{array}$ & $\begin{array}{l}0.086775 \\
0.001286\end{array}$ & $\begin{array}{l}1.123751 \\
0.003676\end{array}$ & $\begin{array}{l}9,896 \\
+306 \\
-306\end{array}$ & 3.1 & $\begin{array}{l}\mathbf{2 , 0 0 2} \\
+88 \\
-88\end{array}$ & 4.40 \\
\hline $\begin{array}{l}\text { Ninkovici, Orujak } \\
43.1705^{\circ} \mathrm{N} \\
19.1731^{\circ} \mathrm{E} \\
1325 \mathrm{~m} \text { a.s.l. }\end{array}$ & M30 & err \pm & $\begin{array}{l}0.056551 \\
0.000128\end{array}$ & $\begin{array}{l}1.042535 \\
0.003658\end{array}$ & $\begin{array}{l}3.181 \mathrm{E}-06 \\
9.323 \mathrm{E}-09\end{array}$ & $\begin{array}{l}0.001054 \\
9.951 \mathrm{E}-06\end{array}$ & $\begin{array}{r}10.732524 \\
1.940077\end{array}$ & $\begin{array}{r}19.1 \\
0.8\end{array}$ & $\begin{array}{l}1.091770 \\
0.010320\end{array}$ & $\begin{array}{l}1.042535 \\
0.003658\end{array}$ & $>350 \mathrm{ka}$ & & $>350 \mathrm{ka}$ & \\
\hline $\begin{array}{l}\text { Lijevno (Veliki Zebalac) } \\
42.8826^{\circ} \mathrm{N} \\
19.2390^{\circ} \mathrm{E} \\
1860 \mathrm{~m} \text { a.s.l. }\end{array}$ & M33 & err \pm & $\begin{array}{l}0.019975 \\
0.000051\end{array}$ & $\begin{array}{l}1.099654 \\
0.004019\end{array}$ & $\begin{array}{l}1.185 \mathrm{E}-06 \\
3.384 \mathrm{E}-09\end{array}$ & $\begin{array}{l}0.000052 \\
6.698 \mathrm{E}-07\end{array}$ & $\begin{array}{l}5.630975 \\
1.017906\end{array}$ & $\begin{array}{l}3.3 \\
0.2\end{array}$ & $\begin{array}{l}0.145890 \\
0.001864\end{array}$ & $\begin{array}{l}1.099654 \\
0.004019\end{array}$ & $\begin{array}{l}\mathbf{1 7 , 1 7 9} \\
+471 \\
-472 \\
\\
{ }^{232} \mathbf{T h} /{ }^{238} \mathrm{U} \\
\text { detrital } \\
\text { molecular } \\
\text { ratio }\end{array}$ & 2.7 & $\begin{array}{l}7,876 \\
+307 \\
-308\end{array}$ & 3.90 \\
\hline $\begin{array}{l}\text { Central Montenegro } \\
\text { [Žabljak] }\end{array}$ & MD1 & err \pm & $\begin{array}{l}1.058730 \\
0.002474\end{array}$ & $\begin{array}{l}0.719115 \\
0.003211\end{array}$ & $\begin{array}{l}4.108 \mathrm{E}-05 \\
1.638 \mathrm{E}-07\end{array}$ & $\begin{array}{l}0.015768 \\
1.429 \mathrm{E}-04\end{array}$ & $\begin{array}{r}3486.2 \\
630.2\end{array}$ & $\begin{array}{l}0.8 \\
0.04\end{array}$ & $\begin{array}{l}1.265266 \\
0.011491\end{array}$ & $\begin{array}{l}0.719115 \\
0.003211\end{array}$ & 3.21 & & & \\
\hline $\begin{array}{l}\text { Central Montenegro } \\
\text { [Kolašin] }\end{array}$ & MD2 & err \pm & $\begin{array}{l}1.058730 \\
0.002474\end{array}$ & $\begin{array}{l}0.719115 \\
0.003211\end{array}$ & $\begin{array}{l}4.108 \mathrm{E}-05 \\
1.638 \mathrm{E}-07\end{array}$ & $\begin{array}{l}0.042597 \\
3.889 \mathrm{E}-04\end{array}$ & $\begin{array}{r}3486.2 \\
630.2\end{array}$ & $\begin{array}{l}2.3 \\
0.1\end{array}$ & $\begin{array}{l}3.418039 \\
0.031259\end{array}$ & $\begin{array}{l}0.719115 \\
0.003211\end{array}$ & 3.21 & & & \\
\hline
\end{tabular}




\subsection{Glacier-climate reconstruction}

The lowermost limit of glacial deposits was used to delimit the former ice cap margins. This was either marked by clear moraine crests, such as at Kolašin, or the lowest outcropping of till exposures. Ice surface profiles were reconstructed using an iterative flowline model (Schilling and Hollin, 1981; Benn and Hulton, 2010). This approach takes into account topographical irregularity below the former ice caps and is preferred to simpler models that assume a horizontal bed, such as the Nye (1952) model applied by Cowton et al. (2009) and Hughes et al. (2010). The limited geomorphological evidence for the upper limit of the former ice caps in central Montenegro, and the very irregular topography of most of the central massifs, meant that an iterative topographically-adjusted flowline model was essential. In this model a basal shear stress of 50-100 kPa was applied. This produced a range of potential surface altitudes for the former ice masses and the most suitable end of this range (50 or $100 \mathrm{kPa}$ ) was constrained using geomorphological evidence of glacial erosion and deposition at certain altitudes.

Ice cap surfaces were separated into different sectors based on flow distributions (cf. Cowton et al., 2009), and then ELAs were estimated by choosing the accumulation area ratio (AAR) with the lowest standard deviation in a sample of ice cap sectors (cf. Osmaston, 2002; Hughes et al., 2010). A similar approach was adopted for discrete valley and cirque glaciers.

\section{Results: geomorphology, stratigraphy and geochronology}

The extent and distribution of glacial deposits in central Montenegro is illustrated in Fig. 1 and the evidence for each massif is outlined below.

\subsection{Durmitor}

Durmitor forms a classic glacial landscape that has been recognised for over 100 years (e.g. Cvijić, 1889, 1903a,b, 1914, 1917; Milojević, 1937, 1950a,b, 1951; Messerli, 1967; Nicod, 1968; Marović and Marković, 1972; Menković et al., 2004; Djurović, 2009), although the existing stratigraphical subdivision of glacial deposits lacks any relative-age (apart from morphostratigraphical position) or geochronological control. Deep valley troughs, separated by sharp arêtes, radiate outwards in all directions from the highest central mountains of Durmitor, which culminate at Bobotov kuk (2523 m a.s.l.) (Fig. 1). Eighteen lakes are present in these valleys bounded by sediment ridges or bedrock in over-deepened hollows. The highest valley areas are characterised by armchairshaped hollows and perennial ice is present at the head of Karlica, below the peak of Šljeme (Kern et al., 2007) and also in caves such as Ledina Pećina (Veselinović et al., 2001).

\subsubsection{Ninkovići Member}

The Ninkovici Member refers to the lowest elevation glacial deposits on Durmitor, which formed during the most extensive recorded glaciation. The type area is situated northeast of Žabljak near the area known as Ninkovići. Numerous gravel pits reveal subsurface sediments near the hill of Orujak (1364 m a.s.l.) (pit location: $43.1705^{\circ} \mathrm{N}, 19.1731^{\circ} \mathrm{E}$, c. $1325 \mathrm{~m}$ a.s.l.) (Fig. $2 \mathrm{~A}$ ). The sediments at this site comprise a diamict with a sandy-silty matrix encapsulating cobble- to boulder-sized clasts. These clasts are predominantly subrounded (Angular [A]: 5\%; Subangular [SA]: 25\%; Subrounded [SR]: 60\%; Rounded [R]: 10\%) and many display evidence of striae (40\%). This gravel pit lies within an area mapped as glacial deposits and moraine crests on the geological map for this area (Mirković and Vujisić, 1989). Moraine mounds are present in
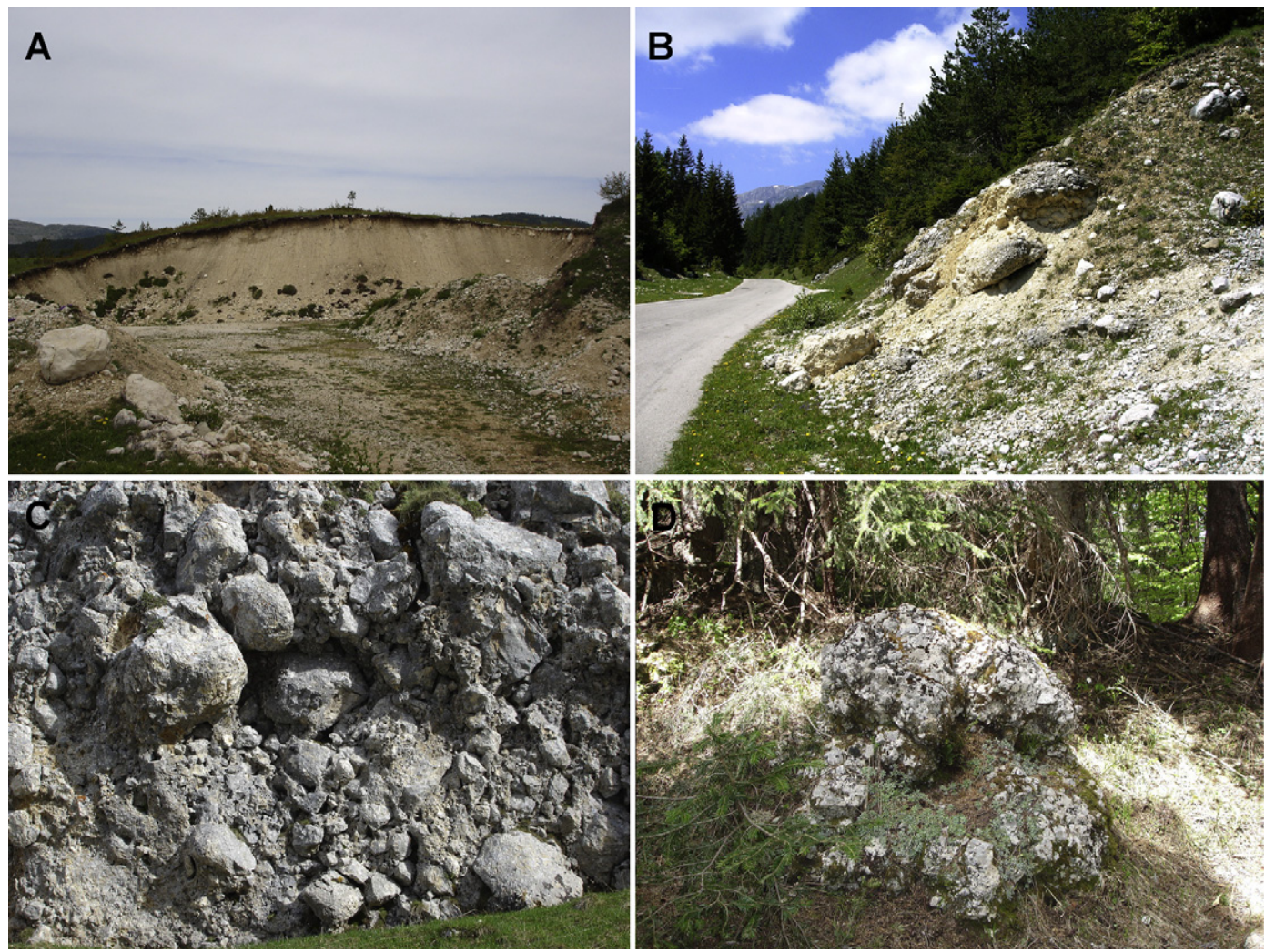

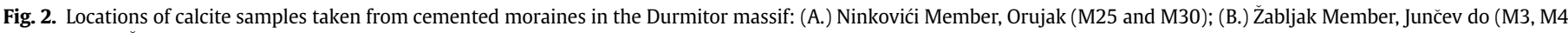
and M6); (C.) Žabljak Member, Donja Ališnica, Glava (M17); (D.) Međed Member, Orun Katun (M11). 
the form of undulating topography (formed in similar materials to that in the Orujak pit) throughout the Ninkovići area (Fig. 1) and extend several kilometres further down-valley with a lower limit at c. 1200-1300 $\mathrm{m}$ a.s.l., near the village of Vrela. Soils are well developed on the surface of the Ninkovići Member moraines. At the Orujak pit, soils reach $>1 \mathrm{~m}$ in thickness and yield a profile development index (PDI) of 43.7. The Orujak moraines are also cemented in several places. Two separate samples (M25 and M30) yielded infinite U-series ages ( $>350 \mathrm{ka}$ ). These samples both displayed a fine-grained spar fabric (micritic; crystal size $<500 \mu \mathrm{m}$ ) and both had ${ }^{230} \mathrm{Th} /{ }^{232} \mathrm{Th}$ ratios of 18.8 and 19.1, respectively. When corrected for detrital contamination the ${ }^{230} \mathrm{Th} /{ }^{234} \mathrm{U}$ activity ratios were still in equilibrium $(\geq 1)$ confirming the infinite ages.

The Ninkovići Member deposits can be traced all around the Durmitor Massif and their lower limit occurs at a range of altitudes. The lowest glacial deposits occur between 600 and $700 \mathrm{~m}$ a.s.l. in the south and west of the main massif, near the town of Šavnik and in valleys draining into the Piva reservoir, such as in Pirnido, several kilometres down-valley from the village of Boričje. Elsewhere, the lower limit of glacial deposits occurs at approximately $1000 \mathrm{~m}$ a.s.l., such as in the Sušica canyon in the north, and near Duži in the south. At their furthest, the lowest glacial deposits in the south near Šavnik are situated c. $20 \mathrm{~km}$ from the centre of the massif (Bobotov kuk). Elsewhere in the west and north, the lowest glacial deposits are situated between 10 and $15 \mathrm{~km}$ from the centre of the massif (Fig. 1).

In the east, glacial deposits are present all over the Jezera plateau which separates Durmitor form neighbouring Sinjajevina. Here, large broad linear moraine crests are orientated north-south with lakes present in the intervening hollows (Riblje jezero, Vražje jezero and Sevarita lokva). These were first mapped by Cvijić (1914). Detailed sedimentological analysis at roadside sections immediately north of Riblje jezero (Fig. 3A) indicates a sand-silt diamict with subrounded and striated clasts which have a strong clast fabric. These characteristics are reproduced in several sections cut in north-south trending moraine ridges immediately north and west of Riblje and Vražje jezero near the medieval tombstones of Grčko groblje. The clast fabric in the glacial sediments of this area indicates a strong dip-direction towards the west. If clast dipdirection in these moraine sections is interpreted as indicative of former ice flow direction, then this would be consistent with ice movement from the Pošćenska dolina, containing the lake of Suva lovka east of Sedlena greda (2227 m a.s.l.). It is also consistent with an interpretation of the Riblje jezero moraines as termino-lateral moraines of a large piedmont glacier (as mapped by Cvijić, 1914). However, this piedmont glacier on the Jezera plateau appears to postdate an earlier phase of glaciation when ice reached past Donja Bukovica and as far as Tusinja (Fig. 1) and the entire Sinjajevina plateau was ice-covered (see below). However, well-developed soils have formed on the moraines of the Jezero plateau and yielded an average PDI of 42.5, similar to those near Ninkovići (43.7). The moraines in these two areas are therefore correlated. This is significant because it means that moraine crests on the Jezera plateau, which are well-within the maximum glacial limits and stratigraphically younger than lower moraines, still belong to the oldest recorded glaciation on Durmitor.

The vertical extent of ice at the maximum extent of glaciation associated with the Ninkovići Member is indicated by the presence of ice-moulded bedrock and perched boulders ( $>1$ m diameter) and moraines on interfluve crests in the central parts of the Durmitor
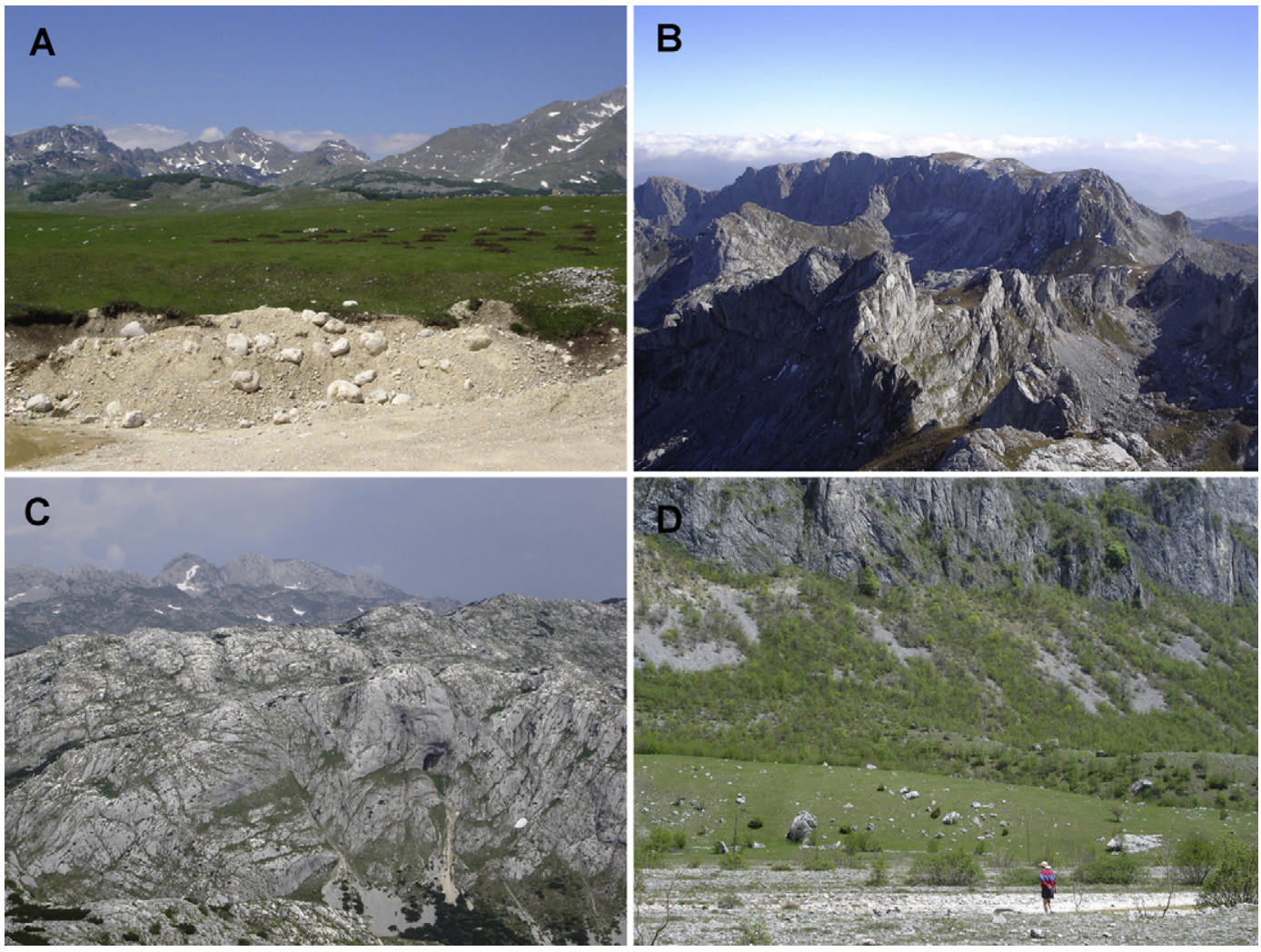

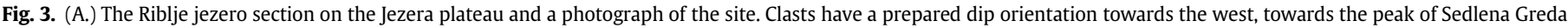

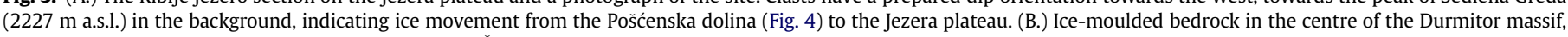

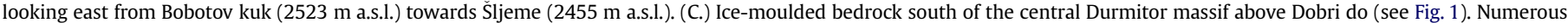

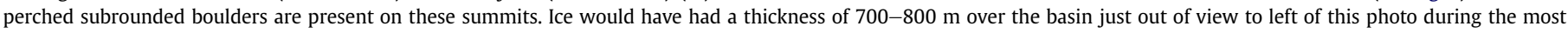
extensive glaciation with ice movement from left-to-right (north-to-south). (D.) Lateral moraines on the eastern side of the Komarnica canyon at an altitude of c. $1000 \mathrm{~m}$ a.s.l. 
massif (Fig. 2B and C). Perched boulders are present above $2100 \mathrm{~m}$ on Štit (2236 m a.s.l.) and above $2050 \mathrm{~m}$ in the col (Sedleni do) between Sedlena Greda (2227 m a.s.l.) and near neighbour Zupci (2148 m a.s.l.) - both south of the highest peak Bobotov kuk (Figs. 1 and 2). The most widespread high-level moraines are present above $2150 \mathrm{~m}$ on the col between the peaks of Planinica (2330 $\mathrm{m}$ a.s.l.) and Bezhimeni vrh (2487 $\mathrm{m}$ a.s.l.). Exposures of diamict with subrounded and striated clasts within a sandy-silty matrix are revealed on the cliffs $600 \mathrm{~m}$ above Škrčko jezero. These sediments are deeply weathered and yielded a PDI of 48.4. In addition to sedimentological evidence for a high-altitude ice limit, many summits display remarkably smooth bedrock surfaces especially on Šljeme (2455 $\mathrm{m}$ a.s.l.) in the central massif and the area to the south of Dobri do (Fig. 3C).

\subsection{2. Žabljak Member}

Distinctive concentrations of large arcuate moraine ridges are present several kilometres up-valley of the lowest and most extensive glacial deposits. The lower limits of these occur at a range of altitudes; as low as $1000 \mathrm{~m}$ a.s.l. in the Komarnica Canyon (Fig. 3D), although more commonly between 1300 and $1500 \mathrm{~m}$ a.s.l. Moraines at altitudes of c. 1400-1500 m a.s.l. at the town of Žabljak provide the type area for the Žabljak Member deposits. Multiple moraine crests several tens of metres high are present in this area. They are found in the town itself and also in nearby valleys, such as the large linear moraine crest named Pitomine to the northwest of the town, which would have separated two large glaciers emanating from the Durmitor massif (Figs. 1 and 8). Sediments are exposed in pits and trenches dug for construction as well as numerous road-cuttings, including in Junčev do on the side of the road leading south out of the town (section location: $43.1509^{\circ} \mathrm{N}$, $19.1269^{\circ}$ E, c. $1455 \mathrm{~m}$ a.s.l.) (Fig. 2B). At this site, sediments consist of diamict with a sandy-silty matrix supporting cobble- to bouldersized clasts. These clasts are predominantly subrounded (A: $10 \%$; SA: 20\%; SR: 60\%; R: $10 \%$ ) and many display evidence of striae (50\%). The sediments are strongly cemented and well-developed secondary calcites cover and bond limestone clasts. Three samples were dated using U-series. Two samples were taken from the top and bottom of a c. 10-15 mm-thick double-layered calcite (regular-shaped prismatic spar crystals) situated between two cobble-sized clasts. These samples (M4 and M3) yielded uncorrected $U$-series ages of $234.6 \pm 12.4$ and $166.2 \pm 5.6 \mathrm{ka}$, respectively. Both samples had low levels of detrital contamination with ${ }^{230} \mathrm{Th} /{ }^{232} \mathrm{Th}$ ratios of 32.4 (M4) and 23.5 (M3) and the corrected ages are therefore within the errors of the uncorrected ages at $231.9 \pm 17.5$ and $162.7 \pm 7.9 \mathrm{ka}$, respectively. A third sample (M6) was taken from a separate cemented horizon in the same section face. This calcite formed irregular-shaped clean prismatic crystals c. $2-5 \mathrm{~mm}$ in diameter and yielded an uncorrected U-series age of $59.2 \pm 1.4 \mathrm{ka}$. The sample had a ${ }^{230} \mathrm{Th} /{ }^{232} \mathrm{Th}$ ratio of 109.7 and represented the cleanest of the central Montenegro calcites with a corrected age $(58.8 \pm 2.0 \mathrm{ka}$ ) very close the uncorrected age. Soils are well developed on the surface of the Žabljak Member moraines. At Junčev do, near the cemented section described above, soils reached $0.5-1 \mathrm{~m}$ in thickness and yielded a profile development index (PDI) of 32.7.

Two further samples for dating were taken west of Žabljak town. Cemented sediments exposed in a section through a moraine on the western side of Žabljak town were also sampled for secondary calcites. The section was revealed in construction workings in 2006, on the road to the Crna jezero (see Table 1 for location data for all samples). This sample (M26) yielded a U-series age of $125.8 \pm 4.7 \mathrm{ka}$. The sample had a ${ }^{230} \mathrm{Th} /{ }^{232} \mathrm{Th}$ ratio of 14.9 and the corrected age was $120.2 \pm 6.4 \mathrm{ka}$. Another cemented section was sampled within the Pitomine moraine northwest of the Žabljak town. This sample (M24) yielded a U-series age of $110.0 \pm 3.8 \mathrm{ka}$. This sample had $\mathrm{a}^{230} \mathrm{Th} /{ }^{232} \mathrm{Th}$ ratio of 17.3 and the corrected age was $105.4 \pm 5.2 \mathrm{ka}$. Whilst these U-series ages are younger than those on the southern moraines of Žabljak town at Junčev do, all of these sites had stronglyweathered soils which yielded similar PDIs (Pitomine $=33.1$; Crna jezero road $=29.8$; Junčev do $=32.7$ ).

U-series dating was also applied at one further site correlated with the Žabljak Member. This was at a trackside section in moraines between the lakes of Suva lovka and Pošćenska jezero. The sample (M14) yielded an uncorrected U-series age of $104.1 \pm 2.9 \mathrm{ka}$. The sample was relatively clean with a ${ }^{230} \mathrm{Th} /{ }^{232} \mathrm{Th}$ ratio of 42.3 and the corrected age is within error of the uncorrected age at $102.5 \pm 4.1 \mathrm{ka}$.

High-level glacial deposits perched on interfluves are contiguous with some Žabljak Member moraines. The best example is in the Donja Ališnica valley, west of the Pitomine moraine. Cemented diamict deposits containing predominantly subrounded and striated cobble- and boulder-sized clasts are present perched c. $200 \mathrm{~m}$ above the valley floor on a ridge named Glava at altitudes of $\mathrm{c}$. 2100-2200 $\mathrm{m}$ a.s.l. (Fig. 2C). These deposits are interpreted as lateral/medial moraines associated with a former ice cap that drained towards Žabljak. A calcite sample (M17) within this cemented till yielded a U-series age of $104.4 \pm 2.7 \mathrm{ka}$. This sample displays evidence of relatively high detrital contamination with a ${ }^{230} \mathrm{Th} /{ }^{232} \mathrm{Th}$ ratio of 4.3 . The corrected age is therefore significantly younger at $88.1 \pm 3.4 \mathrm{ka}$ (Tables 1 and 2 ).

Moraines at several other locations on Durmitor were correlated with the Žabljak Member on the basis of morphostratigraphical position and the degree of soil development. These included moraines in the upper Komarnica canyon in the south, at the village of Boričje in the west and between the lakes of Škrčko jezero and Sušica jezero in the northwest. The U-series results from exposures in the Žabljak area may indicate that the moraines ascribed to the Žabljak Member represent a palimpsest of closely-spaced moraines of different ages. However, these landforms are indistinguishable in terms of surface weathering. Thus, the Žabljak Member is considered as a single unit for the purposes of glacier-climate reconstruction (Table 3 ).

\subsubsection{Međed Member}

Terminal moraines are not present west of Žabljak until one reaches altitudes of c. 1600-1800 $\mathrm{m}$ a.s.l. in the valleys of Orun katun and Indini dolovi, either side of the northern summit of Međed (2217 $\mathrm{m}$ a.s.l.). The twin lakes of Crna jezero, 2-3 km upvalley from Žabljak and immediately northeast of Međed, are not dammed by moraines but by an andesite sill (Mirković and Vujisić, 1989). Clear arcuate terminal moraines above this lake, in the Orun katun and Indini dolovi valleys, represent the type area for the Međed Member. Soils formed on moraines in these valleys yielded PDIs of 17.2 and 16.4, respectively. A calcite sample (M11) was taken from a cemented moraine section in Orun katun (Fig. 2D). This calcite yielded an uncorrected U-series age of $13.7 \pm 0.3 \mathrm{ka}$. The sample had a ${ }^{230} \mathrm{Th} /{ }^{232} \mathrm{Th}$ ratio of 48.9 and the corrected age is close to and within the error of the uncorrected age at $13.4 \pm 0.4 \mathrm{ka}$.

Equivalent moraines at a comparable morphostratigraphical position and with similar soil properties to the Međed Member can be found in all the major valleys of central Durmitor and also on the upper slopes of the outlying peaks of Sedlena greda (2227 $\mathrm{m}$ a.s.l.), Ružica (2141 m a.s.l.) and Veliki Treskavac (2094 m a.s.l.) in the south of the massif. The morphostratigraphical sequence of moraines on Sedlena greda is illustrated in Fig. 4.

\subsubsection{Karlica Member}

The next set of moraines up-valley of the Meded Member moraines in Orun Katun are situated at an altitude of $c$. 
Table 2

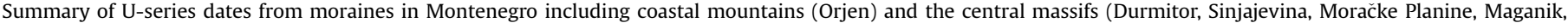
Prekornica and Vojnik). Stratigraphical Members are denoted in bold font.

\begin{tabular}{|c|c|c|c|c|c|}
\hline Unit & & $\begin{array}{l}\text { Corrected } \\
\text { U-series } \\
\text { ages (ka) }\end{array}$ & Soil PDI & Moraine age & Characteristics \\
\hline 6 & $\begin{array}{l}\text { Debeli namet Member } \\
\text { (Durmitor + Central Montenegro) }\end{array}$ & & & AD 1850 to present & Modern glacier \\
\hline 5 & $\begin{array}{l}\text { Gornji do Member (Orjen) } \\
\text { Karlica Member } \\
\text { (Durmitor + Central Montenegro) }\end{array}$ & $\begin{array}{l}9.6 \pm 0.8 \\
8.0 \pm 0.2 \\
10.9 \pm 0.3 \\
10.5 \pm 0.3 \\
9.8 \pm 0.3 \\
9.1 \pm 0.3 \\
7.9 \pm 0.3 \\
2.2 \pm 0.09\end{array}$ & 14.3 & Younger Dryas & $\begin{array}{l}\text { Cirque glaciers } \\
\text { Valley and cirque } \\
\text { glaciers }\end{array}$ \\
\hline 4 & $\begin{array}{l}\text { Reovci Member (Orjen) } \\
\text { Međed Member } \\
\text { (Durmitor + Central Montenegro) }\end{array}$ & $\begin{array}{l}17.3 \pm 0.6 \\
13.9 \pm 0.4 \\
12.5 \pm 0.4 \\
13.4 \pm 0.4\end{array}$ & 16.8 & MIS 2 & $\begin{array}{l}\text { Valley and cirque } \\
\text { glaciers } \\
\text { Valley glaciers }\end{array}$ \\
\hline 3 & $\begin{array}{l}\text { Crkvice Member (Orjen) } \\
\text { Žabljak Member } \\
\text { (Durmitor + Central Montenegro) }\end{array}$ & $\begin{array}{l}124.6 \pm 5.7 \\
124.5 \pm 3.5 \\
124.0 \pm 3.4 \\
102.4 \pm 3.1 \\
120.2 \pm 6.4 \\
105.4 \pm 5.2 \\
104.1 \pm 2.9 \\
88.1 \pm 3.4\end{array}$ & 31.5 & MIS 6 & $\begin{array}{l}\text { Ice caps and valley } \\
\text { glaciers } \\
\text { Ice caps and valley } \\
\text { glaciers }\end{array}$ \\
\hline 2 & $\begin{array}{l}\text { Žabljak Member } \\
\text { (Durmitor }+ \text { Central Montenegro) } \\
\text { Absent from orjen }\end{array}$ & $\begin{array}{l}231.9 \pm 17.5 \\
162.7 \pm 7.9 \\
58.8 \pm 2.0\end{array}$ & 32.7 & MIS 8 or 10 & $\begin{array}{l}\text { Ice caps and valley } \\
\text { glaciers }\end{array}$ \\
\hline 1 & $\begin{array}{l}\text { Knežlaz Member } \\
\text { (Orjen) } \\
\text { Ninkovici Member } \\
\text { (Durmitor + Central Montenegro) }\end{array}$ & $\begin{array}{l}>350 \\
>350 \\
309.3 \pm 42.4 \\
>350 \\
>350 \\
396.6 \pm 87.2 \\
40.7 \pm 1.2 \\
38.8 \pm 1.3\end{array}$ & 43.1 & MIS 12 & Ice caps \\
\hline
\end{tabular}

1800-1850 m a.s.l. below the northeastern cliffs of Savin kuk and at c. 1850-1900 $\mathrm{m}$ a.s.l. just below the pass of Struga leading into the Karlica valley. The Savin kuk moraines are situated in a clear cirque basin 200-300 m from the 450 m-high backwall cliffs. The Struga moraines fill the lower Karlica valley where numerous prominent moraine crests arc across the valley. Soils sampled on the innermost and outermost of these moraine crests yielded similar PDIs of 14.2 and 14.4, respectively. Calcite samples were taken from cemented boulder-rich glacial sediments exposed in sections cut into moraine crests. These yielded uncorrected ages of $23.0 \pm 4.7$ (M5), $10.7 \pm 0.2$ (M22) and $10.6 \pm 0.2 \mathrm{ka}$ (M9). Sample M5 was heavily contaminated with a ${ }^{230} \mathrm{Th} /{ }^{232} \mathrm{Th}$ ratio of just 1.9 . In contrast, the cleanest sample (M9) had a ${ }^{230} \mathrm{Th} /{ }^{232} \mathrm{Th}$ ratio of 99.3 . Sample M22 had a ${ }^{230} \mathrm{Th} /{ }^{232} \mathrm{Th}$ ratio of 12.3 . Thus, the corrected age for sample M9 was closest to the uncorrected age at $10.5 \pm 0.3 \mathrm{ka}$. The other samples were corrected to $10.9 \pm 0.3$ (M5) and $9.8 \pm 0.3 \mathrm{ka}$ (M22).
These corrected ages are consistent with ages obtained from the 'clean' sample M9 supporting the choice of ${ }^{232} \mathrm{Th} /{ }^{238} \mathrm{U}$ ratio (3.21) in the correction technique.

\subsubsection{Debeli namet Member}

The uppermost moraines in the Durmitor massif are found in the highest cirques close to backwall cliffs. Moraines at eight different locations have been dated to the 19th century using lichenometry and a modern glacier still survives at Debeli namet in the Karlica valley (Hughes, 2010b) (situated just south of Međed summit in Fig. 1). In the Karlica valley, the distance between the outermost Debeli namet Member moraines and the outermost Karlica Member moraines is approximately $1.5 \mathrm{~km}$. In this same valley, the Debeli namet Member moraines are situated at c. $2000 \mathrm{~m}$ a.s.l. In the 19th century at the end of the Little Ice Age the eight glaciers covered a total area of c. $0.74 \mathrm{~km}^{2}$ and had a mean

Table 3

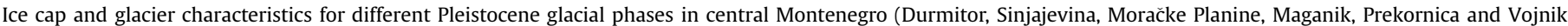
massifs).

\begin{tabular}{|c|c|c|c|c|}
\hline Chronostratigraphy & Number of glaciers & Glacier area & ELA & Characteristics \\
\hline Tymphian Stage ( MIS 5d-2) & 56 & $49 \mathrm{~km}^{2}$ & $1872 \mathrm{~m}$ a.s.l. & Localised ice fields, valley and cirque glaciers \\
\hline Vlasian Stage $(\sim \text { MIS } 6)^{\mathrm{a}}$ & 13 & $721 \mathrm{~km}^{2}$ & $1784 \mathrm{~m}$ a.s.l. & Separate ice caps, valley and cirque glaciers \\
\hline Skamnellian Stage ( MIS 12) & 6 & $1490 \mathrm{~km}^{2}$ & 1607 m a.s.l. & Conjoined ice caps and valley glaciers \\
\hline
\end{tabular}

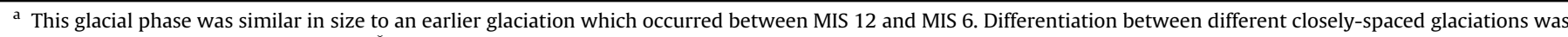
only possible using U-series in one area (Žabljak) and it was not possible to distinguish between the different-aged moraines using soils. 


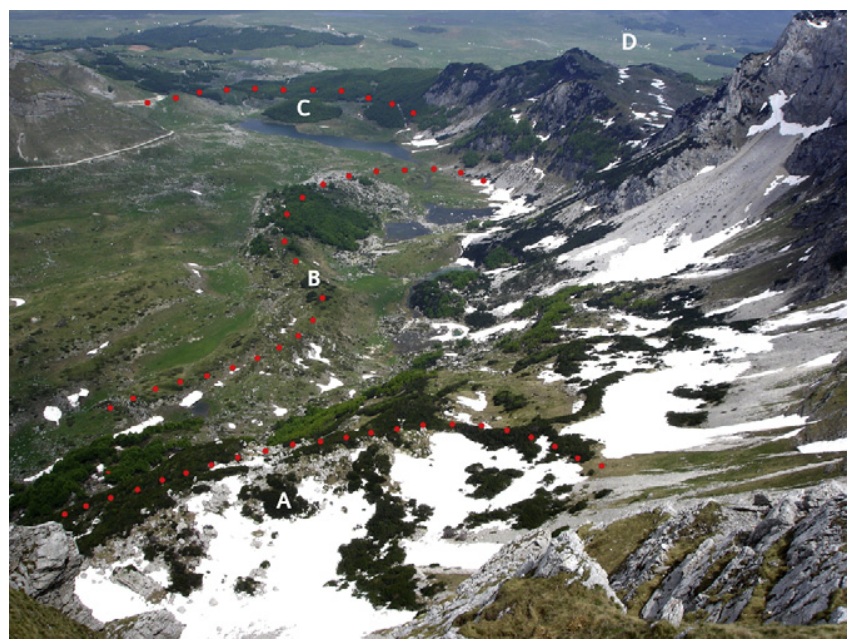

Fig. 4. The morphostratigraphical sequence of moraines in the Pošćenska dolina viewed from the summit of Sedlena greda (2227 m a.s.l.). Based on correlations with other valleys the succession is interpreted as follows: (A.) Karlica Member (Younger Dryas); (B.) Međed Member (Tymphian Stage, MIS 5d-2); (C.) Žabljak Member (Vlasian Stage, MIS 6-10); (D.) Ninkovići Member (Skamnellian Stage, MIS 12).

equilibrium line altitude (ELA) of c. $2170 \mathrm{~m}$ a.s.l. A pronival rampart was also identified on the north face of Minin bogaz (2387 $\mathrm{m}$ a.s.l.) (Hughes, 2010b). Soils are not present on the innermost moraines and soils on the outermost moraines are very thin and yielded a mean PDI of just 2.6. The highest PDI (6.2) was calculated for the Zupci moraines (for site location see Hughes, 2010b).

\subsection{Sinjajevina}

The Sinjajevina massif includes a large undulating plateau above $1600 \mathrm{~m}$ a.s.l. (Fig. 5A) extending over $20 \mathrm{~km}$ southeast from the Jezero plateau on Durmitor and includes the summits of Babin vrh (2013 m a.s.l.) and Veliki Starac (2022 m a.s.l.). The highest peaks are in the far southeast of this massif and culminate at Torna (2217 m a.s.l.). Nicod (1968) recognised evidence for a plateau ice cap on the Sinjajevina plateau which was thick enough to feed valley glaciers in the Tara canyon at Bistrica downstream of Mojkovac: 'Ce plateau a une morphologie glaciaire de fjell, et le glacier de plateau était suffisament épais pour alimenter une langue qui desendait vers le canyon de la Tara, à Bistrica, en aval de Mojkovac' [p. 197]. Glacial deposits are also recorded in several locations over the Sinjajevina plateau and in valleys draining this plateau on geological maps (Osnovna Geološka Karta SFRJ, 1970; Živaljević et al.,
1981; Mirković and Vujisić, 1989). The glacial deposits of the Sinjajevina plateau, and indeed on all other massifs, can be subdivided and correlated with the stratigraphical units defined on neighbouring Durmitor (Table 2).

\subsubsection{Ninkovići Member}

The lowest glacial deposits on Sinjajevina correspond to the Ninkovići Member on Durmitor. These are present below $1000 \mathrm{~m}$ a.s.l. at Bistrica in the north (c. $800 \mathrm{~m}$ a.s.l.), Kolašin in the east (c. $950 \mathrm{~m}$ a.s.l.), Dragovića Polje in the south (c. $700 \mathrm{~m}$ a.s.l.) and at Boan in the southwest (c. $1000 \mathrm{~m}$ a.s.l.). Soils are well-developed on these moraines and produced PDIs of 39.6 and 44.4 at Kolašin and Bistrica, respectively.

The moraines at Kolašin were also mapped by Cvijić (1914). These moraines area present at the end of the U-shaped Lipovo valley (Fig. 5B) at an altitude of c. $950 \mathrm{~m}$ a.s.l. They form a $1 \mathrm{~km}$-long arcuate crest on the west bank of the Tara River. The sediments of this moraine are cemented and these were sampled for secondary carbonates. One sample (M12) yielded an uncorrected U-series age of $416.2 \pm 64.4 \mathrm{ka}$. The ${ }^{230} \mathrm{Th} /{ }^{232} \mathrm{Th}$ ratio of this sample was 5.5 and the corrected age is calculated at $396.6 \pm 87.2 \mathrm{ka}$. The combined soil and U-series data support correlation with the Ninkovići Member moraines in the latter massif.

The $396.6 \pm 87.2 \mathrm{ka}$ age from the Kolašin moraines on Sinjajevina is consistent with calcite formation during MIS 11 and moraine formation during MIS 12. However, this age is at the limit of the Useries technique and involves a large counting error on the parent isotope ${ }^{234} \mathrm{U}$ producing a large uncertainty on the age $(19.15 \%$ on the corrected age).

\subsection{2. Žabljak Member}

In the Lipovo valley, clear moraine ridges are present at Donje Lipovo at c. 1000 m a.s.l., approximately 6 km up-valley of the Kolašin end moraines. However, at Bistrica in the north of the massif, clear end moraines are present only $1.5 \mathrm{~km}$ up-valley of the most extensive moraines at c. 850-900 m a.s.l. Soils on the Donje Lipovo and upper Bistrica moraines yielded PDIs of 28.7 and 30.5, respectively. These are significantly lower (by 25\%) than for soils on the lower Ninkovići Member moraines and are similar to those calculated for Žabljak moraines on Durmitor. No U-series ages were obtained for the Donje Lipovo and upper Bistrica moraines. Thus, these moraines are correlated with the Žabljak Member moraines on Durmitor on the basis of their stratigraphical position and soil PDIs.

\subsubsection{Međed Member}

Concentrations of moraines are present in the upper valley areas leading into cirques, such as at altitudes of c. 1390-1420 m a.s.l. in
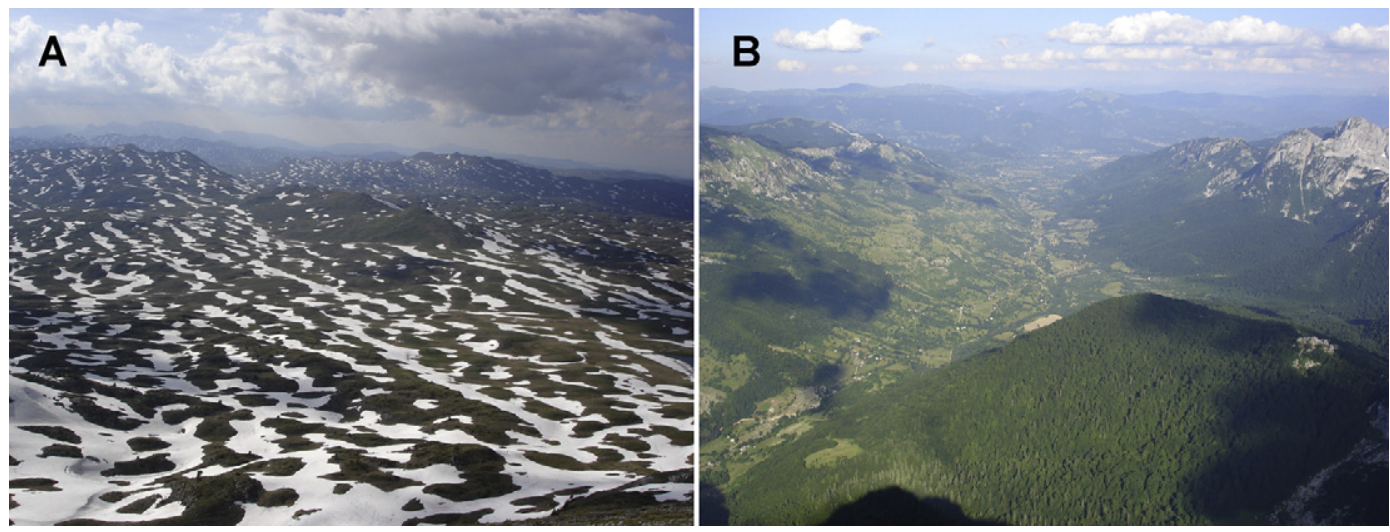

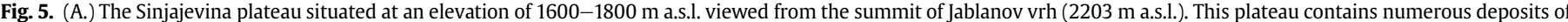

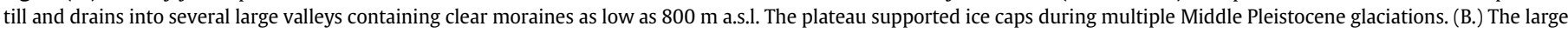

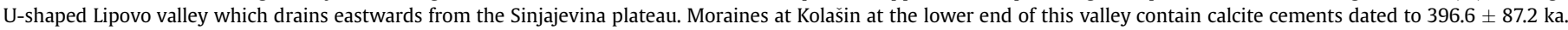


the north-facing valleys of Torna (2217 $\mathrm{m}$ a.s.l.) in the upper Lipovo valley. Similar moraines are present at altitudes of c. 1700-1800 m near Katun Ječmen do on the northern slopes of Gradišta (2215 $\mathrm{m}$ a.s.l.) and at altitudes of $1750-1850 \mathrm{~m}$ in the eastern and northeastern cirques of Jablanov vrh (2203 m a.s.l.), including around the lake of Savina voda $\left(42.8996^{\circ} \mathrm{N}, 19.4201^{\circ} \mathrm{E}\right)$. Soils on the Torna, Gradišta and Jablanov vrh moraines yielded PDIs of 19.1, 20.2 and 18.8 , respectively. These moraines are correlated, on the basis of morphostratigraphical position and soil PDIs, with the Meded Member moraines on Durmitor.

\subsubsection{Karlica Member}

The highest moraines in the Sinjajevina massif are found close to north-facing cirque headwalls around the highest peaks of Torna, Gradišta and Jablanov vrh. The moraines are situated at altitudes between c. 1700 and $1750 \mathrm{~m}$ a.s.l. on Torna and between c. 1900 and $2000 \mathrm{~m}$ a.s.l. on both Gradišta and Jablanov vrh. They are represented by very well-preserved arcuate ridges. Soils are poorlydeveloped on these moraines and PDIs of 12.5 and 10.8 were recorded for moraine surfaces in the northern cirques of Torna and Gradišta, respectively. The soil PDI data supports correlation of these moraines with the Karlica Member on Durmitor.

\subsubsection{Debeli namet Member}

There are at least two sites where moraines exist above those of the Karlica Member on Sinjajevina. One is present in the northern cirque of Gradišta at $42.8839^{\circ} \mathrm{N}, 19.3699^{\circ} \mathrm{E}$, c. $1925 \mathrm{~m}$ a.s.l. Another is present in the northern cirque of Torna (2217 $\mathrm{m}$ a.s.l.), the highest peak of this massif. Here, the moraine ridge is situated at an altitude of c. $1850-1900 \mathrm{~m}$ a.s.l. $\left(42.8679^{\circ} \mathrm{N}\right.$, $19.3762^{\circ} \mathrm{E}$ ). It was not possible to obtain U-series or soil PDI data for these moraines. It is lower than the Debeli namet Member moraines on Durmitor. A large snowfield was present in this site in July 2006. Furthermore, the mean thalli diameter of the largest 5 lichens on this moraine (from a sample size of 50 lichens) was $78.5 \mathrm{~mm}$; this corresponds to a surface age of 117 years based on the lichen growth curve established for Durmitor (Hughes, 2007, 2010b). These data indicate that the highest cirque moraine on Torna is equivalent to the Little Ice Age moraines of the Debeli namet Member on Durmitor.

\subsection{Moračke Planine, Maganik and Prekornica massifs}

The Moračke Planine form the watershed and source the Morača (alternative spellings include Moračke and Moracha) River, which drains southwards towards Lake Skadar and the Adriatic Sea. The northwest part of this massif is also known as 'Lola' on topographical maps of the Vojnogeografski Institut (Military Geographical Institute, Belgrade). The highest peak is Kapa Moračka (2226 $\mathrm{m}$ a.s.l., also known as Lastva). Maganik also forms the western watershed of the Morača River and culminates at Međeđi vrh (2139 m a.s.l.). Prekornica (1927 m a.s.l.) lies $15 \mathrm{~km}$ to the southwest (Fig. 1).

Liedtke (1962) identified evidence for a large ice cap over these massifs and mapped moraines delimiting this ice cap west of the Lukavica plateau (situated between Moračke Planine and Maganik) and in the Morakovo valley on Prekornica (Fig. 1). In common with Cvijić (1914), Liedtke mapped two sets of moraines and named these as Altmoränen and Würm, the latter referring to the last cold stage in the Alpine chronostratigraphy. However, as on Durmitor and Sinjajevina, the glacial stratigraphy is more complex than this and the evidence is outlined below. Correlations are more tentative than those made between Durmitor and Sinjajevina because soil and U-series datasets are not as extensive. Nevertheless, correlations can be made based on comparisons with the detailed datasets complied for Durmitor.

\subsubsection{Ninkovići Member}

The lowest glacial deposits occur at altitudes of c. 600-800 $\mathrm{m}$ a.s.l. in the east of the Moračke Planine, Maganik and Prekornica massifs. In the north, south and west the lowest glacial deposits occur at altitudes of c. 800-1000 m a.s.l. At Gradačka poljana and west of Dažník (1625 m a.s.l.) in the western Moračke Planine, soils on the outermost moraines yielded PDIs of 47.2 and 40.2 , respectively, similar to soils on the Ninkovići Member deposits on Durmitor and Sinjajevina.

These moraines can be traced northwards where they merge with glacial deposits north of Vojnik, and southwards west of the village of Gvodz and summits of Dažník (1625 m a.s.l.) and Caplijeznica (1319 $\mathrm{m}$ a.s.l.). Ice also reached the village of Oblatno in the southwest, where the limit of moraines has been destroyed (and sections revealed) by a large quarry. Very large moraines ( $>50 \mathrm{~m}$ in height) are also present in the Morakovo valley northwest of Prekornica. Moraines are also widespread in valleys south of this massif. In the southeast the lowest moraines are present in valleys above the Morača and Mrvtica canyons. In the eastern Moračke Planine glacial deposits are present in the Dragovića Polje valley and in valleys draining into this from the north face of Kapa Moračka (2226 $\mathrm{m}$ a.s.l.). Moraine ridges are particularly well-defined in the upper reaches of the Morača River at Ljevista. Up-valley of the moraines at Aluga near Ljevista, cemented screes mantle oversteepened glaciated valley-sides. Two samples yielded U-series ages of $54.0 \pm 1.1$ (M20) and $59.0 \pm 1.3 \mathrm{ka}$ (M23). These two samples had ${ }^{230} \mathrm{Th} /{ }^{232} \mathrm{Th}$ ratios of 3.4 and 2.5 , respectively, and the corrected ages are $40.7 \pm 1.2$ and $38.8 \pm 1.3 \mathrm{ka}$. These represent minimum ages for both the age of the screes and minimum ages for the glaciers which formed this valley. Whilst these are much younger than the U-series ages from the Ninkovići Member moraines on Durmitor and Sinjejvina, they are older than the U-series ages obtained from the Međed Member moraines on Durmitor. Based on the dates alone, the Aluga moraines must therefore be correlative with the Ninkovići or Žabljak Member deposits on Durmitor. However, soils formed on the Aluga moraines yielded PDIs of 45.3. Together, the presence of such strongly-weathered soils and the fact that the Aluga moraines are the lowest in this area suggests a correlation with the Ninkovići Member deposits of Durmitor.

\subsection{2. Žabljak Member}

End moraines up-valley of the Ninkovići Member moraines in the Moračke Planine, Maganik and Prekornica massifs are present at altitudes between 1100 and $1500 \mathrm{~m}$ a.s.l. In the southwestern area of the Moračke Planine these moraines are very close to those ascribed to the Ninkovići Member. These multiple limits were mapped by Liedtke (1962) but all were ascribed to the same glacial phase (Würm) in the Dažník (1625 m a.s.l.) area. Soils on the inner moraines just to the south of this mountain yielded PDIs of 28.1 and soils on lower moraines in the same valley yielded PDIs of 40.2 (correlated with the Ninkovići Member - see above). This suggests that these moraines are widely separated in age and the inner moraines are correlated with the Žabljak Member moraines of Durmitor. Elsewhere in the Moračke Planine, Maganik and Prekornica massifs moraines are correlated with the Žabljak Member moraines of Durmitor on the basis of morphostratigraphical position relative to the lowest, Ninkovići Member, glacial deposits. Important type sites which helped to constrain the overall delimitation for this member included clear end moraines southeast of Donja Bijela and Boan in the northwest Moračke Planine, the northern valleys of Kapa Moračka (2226 m a.s.l.), south of Kapetanovo jezero and on the plateau between Prekornica and Maganik. 


\subsubsection{Međed Member}

Moraines above those of the Žabljak Member are restricted to the highest valleys and cirques of the Moračke Planine, Maganik and Prekornica massifs at altitudes of 1600-1900 m a.s.l. The type site for these deposits in these massifs is at Kapetanovo jezero where moraines surround the southern end of the lake (Fig. 1). Soil data are not available for these moraines and correlations with the Žabljak Member are made of the basis of morphostratigraphical position.

\subsubsection{Karlica Member}

Cirque moraines in the Moračke Planine, Maganik and Prekornica massifs occur at altitudes between 1900 and $2000 \mathrm{~m}$ a.s.l. in the Moračke Planine and Maganik massifs. Equivalent moraines are absent from Prekornica. The type sites for these moraines are situated in the northern cirques of the Moračke Planine. Secondary carbonate cements were revealed in stream sections cut through a clear arcuate moraine ridge bounding a small lake in the northeastern cirque of Lijevno (2081 m a.s.l.), c. $1.5 \mathrm{~km}$ northeast of Veliki Zebalac (2129 $\mathrm{m}$ a.s.l.) (Fig. 6A). Three samples were dated using Useries. These samples (M13, M28 \& M33) yielded uncorrected ages
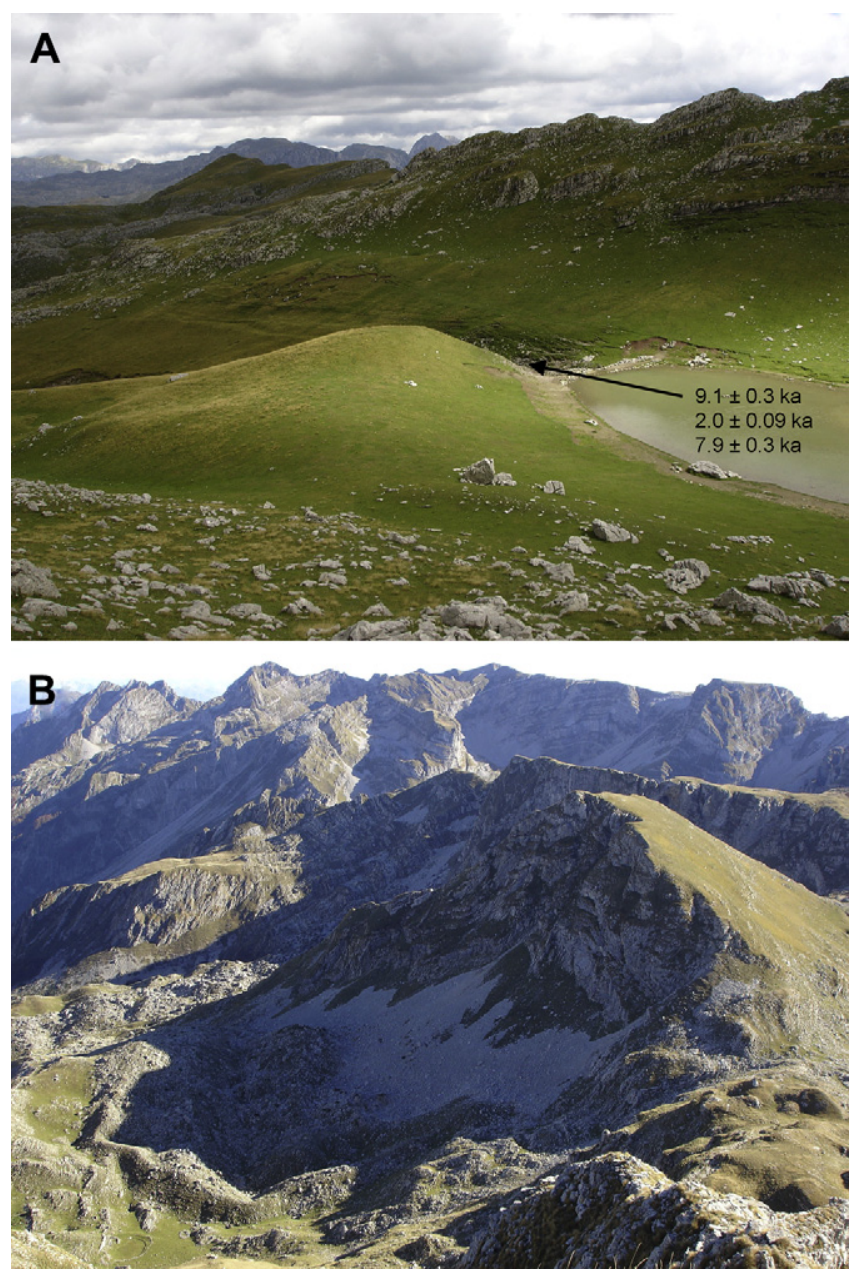

Fig. 6. A. A moraine ridge containing cemented by secondary carbonates bounding a small lake in the northeastern cirque of Lijevno (2081 m a.s.l.), c. $1.5 \mathrm{~km}$ northeast of Veliki Zebalac (2129 $\mathrm{m}$ a.s.l.) in the Moračke Planine $\left(42.8826^{\circ} \mathrm{N}, 19.2390^{\circ} \mathrm{E}, \mathrm{c}\right.$. $1860 \mathrm{~m}$ a.s.l.). A U-series age of $\mathbf{9 . 1} \mathbf{\pm} \mathbf{0 . 3} \mathrm{ka}$ from calcite cementing the moraine provides a minimum age for the landform and it is likely that this feature correlates with the Karlica Member on Durmitor and the Younger Dryas Chronozone (12.9-11.7 ka). B. Many of the highest cirques of the in the Moračke Planine contain similar moraines such as this one at $42.8654^{\circ} \mathrm{N}, 19.2309^{\circ} \mathrm{E}, \mathrm{c} .1825 \mathrm{~m}$ a.s.l. (bottom left of the photograph). of $14.9 \pm 0.3 \mathrm{ka}, 9.9 \pm 0.3 \mathrm{ka}$ and $17.2 \pm 0.4 \mathrm{ka}$. However, these samples were contaminated with ${ }^{230} \mathrm{Th} /{ }^{232} \mathrm{Th}$ ratios of $2.9,2.5$ and 3.3 , respectively. The corrected ages were $9.1 \pm 0.3 \mathrm{ka}$ (M13), $2.0 \pm 0.09 \mathrm{ka}(\mathrm{M} 28)$ and $7.9 \pm 0.3 \mathrm{ka}(\mathrm{M} 33)$. These minimum ages are important because they indicate that these moraines do not correlate with the Debeli namet Member moraines, which have been dated to the last few hundred years (Hughes, 2010b). Thus, these moraines are correlated with the Karlica Member moraines which yielded similar U-series ages (to sample M13) on Durmitor. Similarly-positioned moraines can be found in many of the highest cirques in the Moračke Planine, such as at $\left(42.8654^{\circ} \mathrm{N}, 19.2309^{\circ} \mathrm{E}, \mathrm{c}\right.$. 1825 m a.s.l.) (Fig. 6B).

\subsubsection{Debeli namet Member}

In at least two of the highest cirques of Kapa Moračka (2226 $\mathrm{m}$ a.s.l.) there are boulder ridges close to backwall cliffs, upvalley of the Karlica Member moraines at altitudes of c. 2000 m a.s.l. In October 2005, these were situated in front of small snowfields. It is possible that these correlate with the recent glacial deposits of the Debeli namet Member found on Durmitor and Sinjajevina. However, no lichen data were collected for these moraines and this correlation remains tentative.

\subsection{Outlying areas - Vojnik}

Vojnik (1998 m a.s.l.) is situated northwest of Moračke Planine. Three generations of moraines are present in the northern valleys and cirques and these are correlated with the various members found on Durmitor on the basis of stratigraphical position. The lowest moraines occur down to altitudes of 900-1200 $\mathrm{m}$ a.s.l. on the northern slopes draining in to the Komarnica canyon. Moraines are also present in west-facing cirques of the highest Vojnik summit (1998 $\mathrm{m}$ a.s.l.). In the east of this massif, the lowest moraines merge with glacial deposits of the Moračke Planine. The lowest moraines all belong to the Ninkovići Member. A younger set of moraines is present several kilometres up-valley of the lowest glacial deposits. These moraines were formed by small valley glaciers emanating from the northern cirques of Vojnik. Extensive sections through the lowest of these moraines are revealed in cuttings by the main road at c. $1050 \mathrm{~m}$ a.s.l. near to the hamlet of Mokro, to the southwest of Šavnik. These moraines are correlated with the Žabljak Member deposits on Durmitor. The highest moraines on Vojnik are found in the highest cirque dolines at $c$. 1500-1600 m a.s.l. This third stratigraphical unit correlates with the Međed Member on Durmitor. Glacial deposits at higher elevations are not present on Vojnik.

\section{Results: glacier reconstruction}

\subsection{Ninkovići Member ice masses (Skamnellian Stage, 470-420 ka MIS 12)}

The largest glaciation in central Montenegro was characterised by four conjoined ice caps covering an area of c. $1483 \mathrm{~km}^{2}$. Several smaller glaciers also formed on satellite mountains such as Vojnik (Fig. 7).

The AAR with the lowest standard deviation for 17 sectors of the former ice caps was 0.8 - the same as that derived for the Orjen ice cap on the Adriatic coast. This is consistent with the parabolic surface profile of most ice caps which results in the largest surface areas at a relatively narrow range of altitudes towards the centre of the ice cap. However, for valley glaciers such as those on Vojnik, the AAR with the lowest standard deviation was 0.6 , which is consistent with AARs observed on modern valley glaciers (Porter, 1975). 


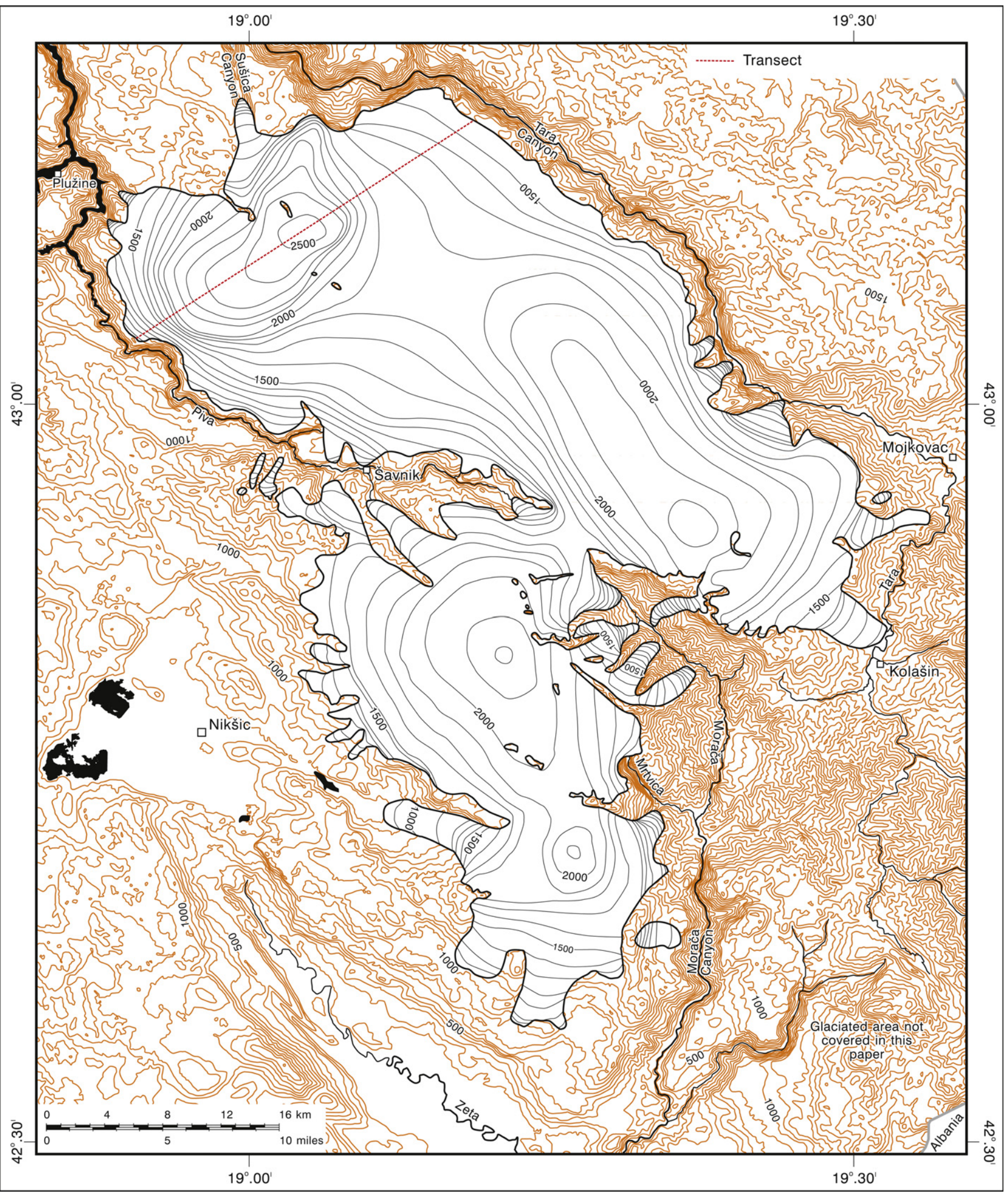

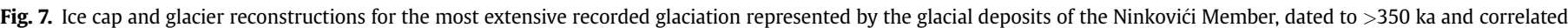

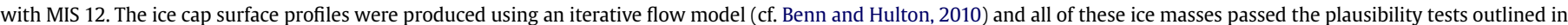
$\mathrm{Ng}$ et al. (2010). 


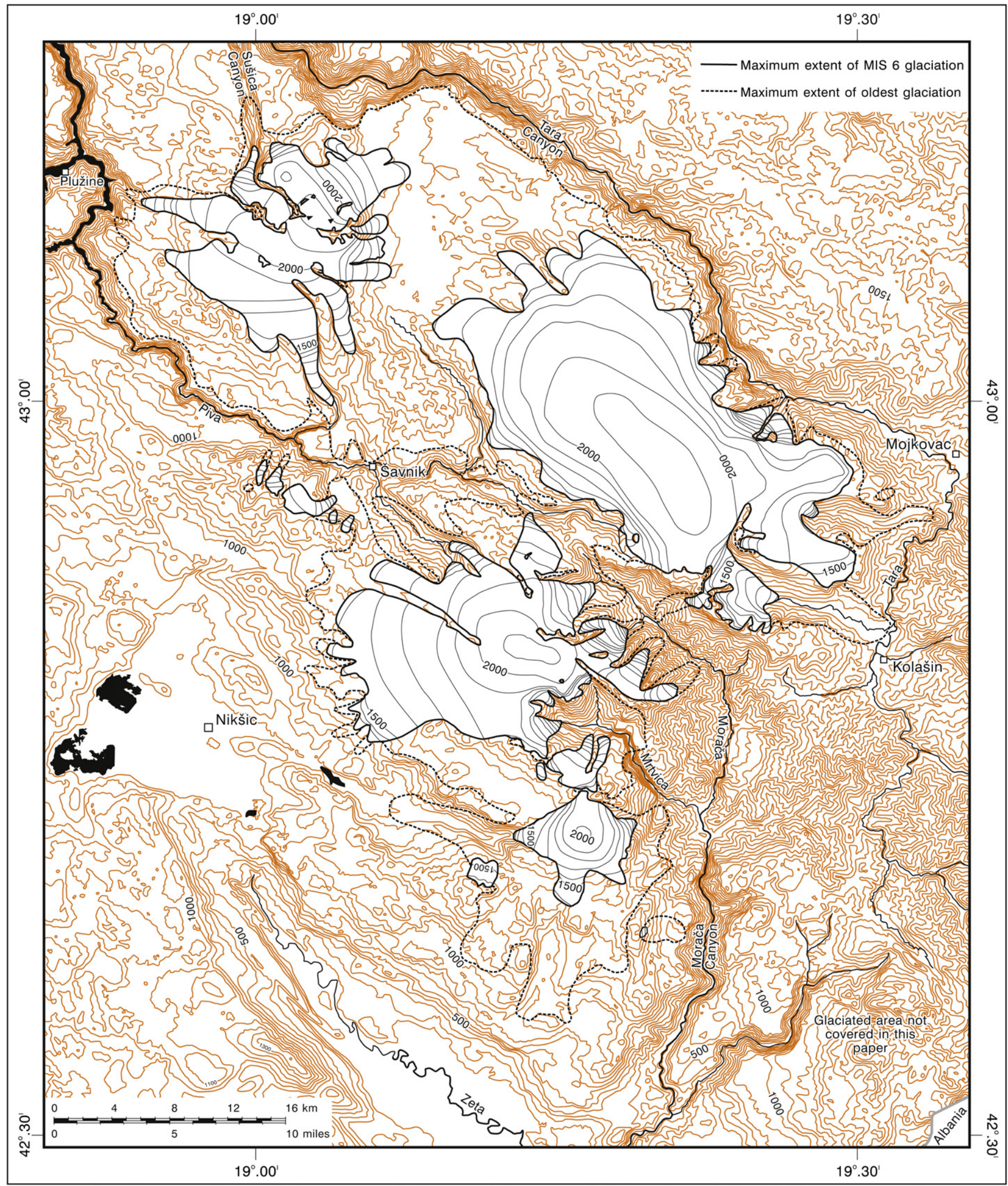

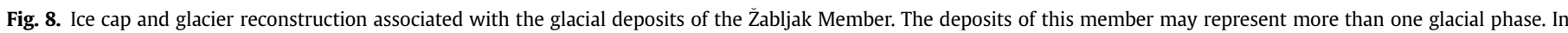

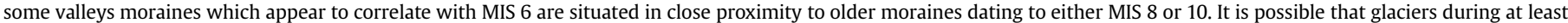
two separate cold stages over the period MIS 10-6 were similar in size. See Table 2 for U-series dates and text for details. 
Thus, separate AARs were used to calculate ELAs on the ice caps (0.8) and the valley glaciers (0.6).

The mean ELA of the ice caps and glaciers in central Montenegro was $1607 \mathrm{~m}$ a.s.l. However, there were large variations in the ELAs of different sectors of the ice caps and individual glaciers. Glaciers with the lowest ELAs formed in the Prekornica massif (ELAs: 1500-1600 m a.s.l.) whilst glaciers with the highest ELAs formed on the northeastern flanks of Durmitor and Sinjajevina.

The large-scale geomorphology of valley systems on Durmitor suggests that ice flowed radially outwards from the centre of the massif - as recognised by Djurović (2009). The ice flow model predicts an ice surface altitude situated at c. $2500-2600 \mathrm{~m}$. This is above the altitude of the highest peaks and would have covered most peaks under $2500 \mathrm{~m}$ a.s.l. Ice would have had a thickness of 700-800 m over Dobri do, an enclosed basin south of the massif centre (Fig. 9). Ice radiated from an ice centre situated between Šljeme (2455 m a.s.l.) and Bobotov kuk (2523 m a.s.l.) draining into large troughs between sharp-crested arêtes, such as Štit (2236 m a.s.l.), Zupci (2309 m a.s.l.), Terzin Bogaz and Međed (2252 $\mathrm{m}$ a.s.l.). Perched boulders situated on these arêtes indicate that they were overridden by ice during the maximum extent of glaciation, thus supporting the ice cap model. The only summits to remain ice-free were those of Bobotov kuk (2523 m a.s.l.) and Bezhimeni vrh (2487 $\mathrm{m}$ a.s.l.) and the intervening arête. These would have formed nunataks situated slightly west of the ice centre during the most extensive recorded glaciation.

Almost the entire Sinjajevina plateau was covered by an ice cap when the Ninkovići Member moraines were formed. The ice cap reached a surface altitude of 2200-2300 m a.s.l. (above modern sea-level) and reached a thickness of c. 300-400 $\mathrm{m}$ at its centre. The highest summits ( $>2200 \mathrm{~m}$ a.s.l.) in the east of the massif stood above the ice cap surface (Fig. 7).

The Sinjajevina and Moračke Planine ice caps were contiguous and the col between the upper Piva and Morača catchments separating these two massifs was characterised by an area of ice confluence about $100 \mathrm{~m}$ thick. The centre of the Moračke Planine was situated between the peak of Veliki Žurim (2035 m a.s.l.) and the lake of Kapetanovo jezero and stood at a surface altitude of $c$. $2200 \mathrm{~m}$ a.s.l., and c. $400 \mathrm{~m}$ thick at its maximum. Away from the ice centre, several peaks above $2000 \mathrm{~m}$ a.s.l. would have stood above the ice cap as nunataks, including the main ridge of the Kapa Moračka (2226 m a.s.l.) that would have separated the ice cap from cirque and valley glaciers on the northern slopes (Fig. 7). The Moračke Planine ice cap coalesced with an ice cap that formed between Maganik and Prekornica where ice reached an altitude of c. $2200 \mathrm{~m}$ a.s.l. and drained radially to produce large valley glaciers in the Morakovo valley north of Prekornica and in valleys to the south (Fig. 7).

Three valley glaciers formed in the outlying Vojnik massif. A fourth larger ice mass was present in the eastern cirques and formed an ice field that was conjoined with the Moračke Planine ice cap.

\section{2. Žabljak Memberice masses (Vlasian Stage, 190-130 ka MIS 6)}

The U-series data suggest that by the Žabljak Member moraines may record two separate glacial cycles. However, on the basis of the available data it is impossible to separate these two phases in the geomorphological record and, for the purpose of glacier reconstruction, the Žabljak Member ice masses are considered as a single event (or alternatively as different generations of ice but of equal size).

The Žabljak Member moraines were formed by several separate ice caps, ice fields, valley and cirque glaciers (Fig. 8). Thirteen separate ice masses covered a total area of $721 \mathrm{~km}^{2}$ (Table 3). The largest ice cap formed over Sinjajevina and extended over an area of $352 \mathrm{~km}^{2}$ followed by the Moračke Planine ice cap $\left(187 \mathrm{~km}^{2}\right)$, the Durmitor ice field $\left(129 \mathrm{~km}^{2}\right)$, then a smaller ice cap south of Maganik $\left(32 \mathrm{~km}^{2}\right)$. All other ice masses were cirque or valley glaciers, such as in the Vojnik massif where five cirque and valley glaciers covered a total area of c. $7.2 \mathrm{~km}^{2}$.

Again, a flow model was used to constrain the upper altitude of the ice caps. The Sinjajevina and Moračke Planine ice caps reached a surface altitude of $2100-2200 \mathrm{~m}$ a.s.l. and an ice thickness of 200-300 m. In the Durmitor massif numerous arêtes and nunataks would have separated ice into different valleys with a central ice field situated at an altitude of 2300-2400 m a.s.l. over Valoviti do, northeast of the highest peak Bobotov kuk. A large ice field also formed to the south of this peak over Dobri do which fed several outlet glaciers. Ice thickness below these ice fields reached c. $400 \mathrm{~m}$ (Fig. 9).

The AAR with the lowest standard deviation for different sectors of the former ice caps on Sinjajevina, Moračke Planine and Maganik was 0.8 - in line with the earlier Ninkovići Member ice caps. However, the different sectors of the Durmitor massif were characterised by outlet valley glaciers and this produced a lowest standard deviation at an AAR of 0.6 and this was used to calculate ELAs on these and other valley and cirque glaciers. The mean ELA for all Žabljak Member ice masses was $1784 \mathrm{~m}$ a.s.l. The lowest ELAs were on the Prekornica glaciers (c. $1545 \mathrm{~m}$ a.s.l.) followed by the Vojnik, Maganik, Moračke Planine and Durmitor ice masses (mean ELAs of 1595, 1652, 1670 and $1798 \mathrm{~m}$ a.s.l., respectively). The largest

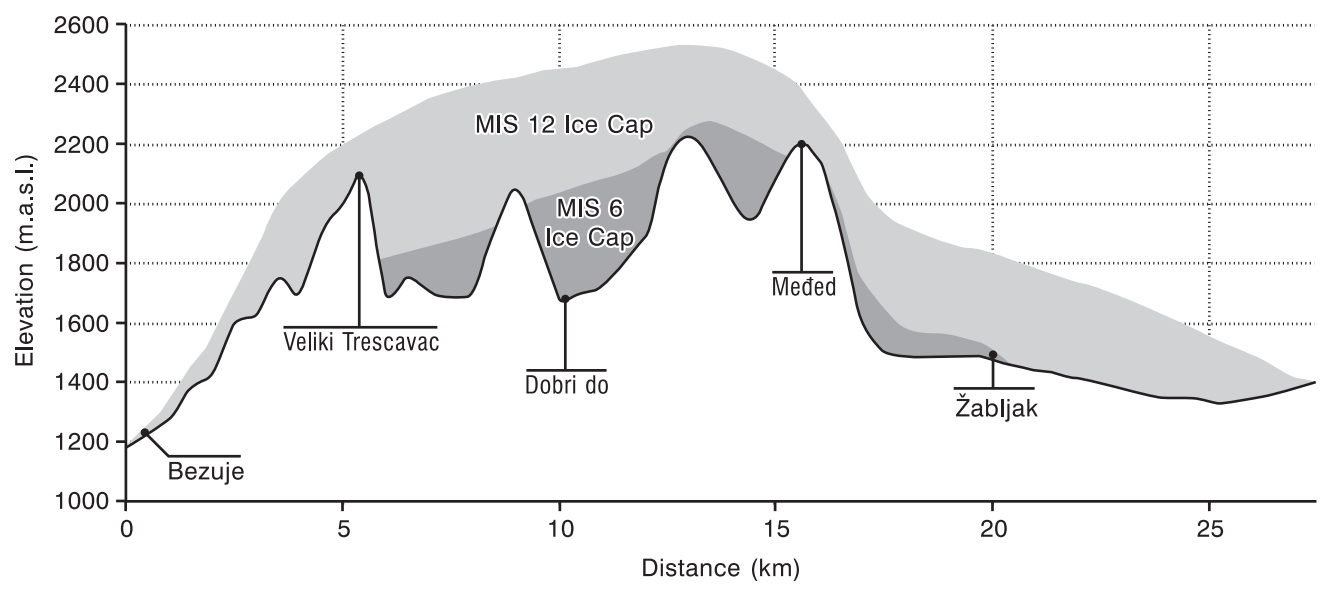

Fig. 9. Ice cap profiles over Durmitor during MIS 12 and MIS 6 along the transect depicted in Fig. 7. 
ice cap, on Sinjajevina, had the highest ELAs with a mean of $1842 \mathrm{~m}$ a.s.l.

\subsection{Međed Member ice masses (Tymphian Stage, MIS 5d-2 $110-11.7 \mathrm{ka}$ )}

The Međed Member ice masses were much smaller than the earlier recorded glaciations and ice covered a total area of c. $49 \mathrm{~km}^{2}$ or just over $3 \%$ of the area of the earlier Ninkovići Member ice caps (Table 3, Fig. 10). The largest ice masses formed on Durmitor where 17 glaciers covered an area of $19.8 \mathrm{~km}^{2}$. The largest ice field and associated outlet glaciers covered an area of c. $7.9 \mathrm{~km}^{2}$ and was centred in Ledeni do, which is situated between Bobotov kuk and Šljeme in the centre of the massif, and from where ice breached the drainage divide to radiate northwards and southwards (Fig. 10). Whilst the largest outlet glaciers of the ice field drained north, 8 individual cirque and valley glaciers faced southwards (either in part or in entirety) with others occupying a range of aspects.

Sinjajevina supported only 10 small cirque and valley glaciers during the maximum extent of glaciation during the last cold stage and they covered a total area of $6.2 \mathrm{~km}^{2}$. The largest glaciers $\left(>1 \mathrm{~km}^{2}\right)$ formed in the northern cirques of Gradista ( $2215 \mathrm{~m}$ a.s.l.) and the eastern cirques of Jablanov vrh (2203 $\mathrm{m}$ a.s.l.). All of these glaciers were north- or northeast-facing (Fig. 10).

In the Moračke Planine 15 glaciers covered a total area of $17.6 \mathrm{~km}^{2}$. An ice field covering an area of $5.9 \mathrm{~km}^{2}$ was present in the centre of the massif between Kapetanovo jezero and Kapa Moračka. Two of the three outlet glaciers from this ice field faced south whilst one faced east. However, 10 of the 15 glaciers in the Moračke Planine were north- or east-facing.

On Maganik, 7 small cirque glaciers occupied north- and northeast-facing cirques and covered a total area of $2.7 \mathrm{~km}^{2}$. Further south on Prekornica, three small cirque glaciers covered a total area of just $0.4 \mathrm{~km}^{2}$. Two of these occupied north-facing cirques near the summit of Prekornica (1927 m a.s.l.) whilst another occupied an east-facing cirque overlooking the Morača canyon below the summit of Kamenik (1815 m a.s.l.).

In the outlying Vojnik massif, four small glaciers occupied the northern cirques and covered a total area of $2.2 \mathrm{~km}^{2}$.

ELAs were calculated using an AAR of 0.6, which for all the glaciers was the AAR with the lowest standard deviation. The mean ELA of all glaciers was $1872 \mathrm{~m}$ a.s.l. The lowest ELAs were in the Prekornica massif (mean ELA: $1655 \mathrm{~m}$ a.s.l.). The highest ELAs were in the Sinjajevina massif where the mean ELA was $1952 \mathrm{~m}$ a.s.l. In the Karlica valley on Durmitor, which contains the last known surviving glacier in Montenegro (Debeli namet - see below), the ELA during the maximum extent of glaciation of the last cold stage was c. $1890 \mathrm{~m}$ a.s.l.

\subsection{Karlica Member (Younger Dryas, 12.9-11.7 ka) and Debeli namet Member (late Holocene) ice masses}

Numerous $(>40)$ cirques in central Montenegro contain moraines that can be correlated with the Karlica Member moraines on Durmitor. The number, extent and ELAs of these glaciers are the subject of further investigation. Equivalent features to the Debeli namet moraines, which formed during the late Holocene, can also be identified in numerous $(>15)$ cirques across central Montenegro although, again, more research is required in order to identify the number of glaciers and achieve accurate reconstructions of extent and altitude. The modern Debeli namet glacier has an ELA of $c$. $2150 \mathrm{~m}$ a.s.l., although this is well below the regional ELA and is the product of strong local topoclimatic controls, such as shading, avalanching and windblown snow (Hughes, 2008).

\section{Discussion}

The large Middle Pleistocene glaciations of Montenegro accord with evidence for major glaciations in Croatia and Greece that predate the last glacial cycle. In the Pindus Mountains of northern Greece, 19 glaciers on Mount Tymphi, Smolikas and Vasilitsa covered a total area of $72.6 \mathrm{~km}^{2}$ during the most extensive glaciation (Hughes, 2004). The Montenegro glaciations were an order of magnitude larger. The total area of ice over Orjen and the massifs of central Montenegro described in this paper was $1648 \mathrm{~km}^{2}$. This represents $12 \%$ of the total area of Montenegro $\left(13,812 \mathrm{~km}^{2}\right)$.

The large size of the Middle Pleistocene glaciations - especially the largest which is correlated here with MIS 12 - would have had profound implications for the regional environment. Such large ice masses would have represented a significant orographic barrier and caused atmospheric cooling over the Balkans. This would have strengthened the temperature contrast between the Balkan landmass and the Mediterranean Sea, which today results in some of the highest precipitation values in Europe as well as the phenomenon of Bora winds in Dalmatia (Lazić and Tošić, 1998). The effects of this land-sea temperature contrast during the largest Pleistocene glaciations would have included sustained high values of precipitation in the western Balkans, a marked inland precipitation gradient, and even stronger katabatic winds than occur today.

Strong inland precipitation gradients are reflected by the ELAs of the former glaciers in Montenegro during all cold stages. On the coastal mountain of Orjen (1894 m a.s.l.), the MIS 12 ice cap had a mean ELA of $1256 \mathrm{~m}$ a.s.l. whereas the inland ice caps of central Montenegro has a mean ELA of $1607 \mathrm{~m}$ a.s.l. On the inland ice caps there was a strong gradient between the Prekornica massif in the south (closest inland massif to the Adriatic Sea), with an ELA of $1520 \mathrm{~m}$ a.s.l., and the northeastern slopes of Sinjejvina in the north, with an ELA of 1700-1800 m a.s.l. A similar pattern occurred during all glacial cycles. For example, during the maximum extent of ice during the last cold stage (MIS 5d-2) the glaciers on Orjen had a mean ELA of $1456 \mathrm{~m}$ a.s.l., whilst the inland central massif had a mean ELA of $1872 \mathrm{~m}$ a.s.l. - again with a strong gradient between the southern and northern massifs. The rising inland ELA gradient was slightly greater during the last glacial cycle. This may be because of the predominance of cirque and valley glaciers where mass balance is controlled over a small area (i.e. the single cirquevalley), unlike the larger Middle Pleistocene ice caps which radiated mass from ice cap centres and where mass balance reflected a larger-scale average climate. This is highlighted by the different sizes of the ice masses over Sinjajevina during the different cold stages. This massif supported the largest ice cap centres during the Middle Pleistocene but only a small number and area of glaciers during the last cold stage. For the latter, the difference in ELAs between Orjen and the inland massifs was $416 \mathrm{~m}$. Based on a distance of $65 \mathrm{~km}$ between Orjen and Durmitor massifs, this equates to a rise in ELAs of c. $6.4 \mathrm{~m}$ per $\mathrm{km}$, or a rise of $100 \mathrm{~m}$ for every $15 \mathrm{~km}$ inland. This is likely to explain why there is evidence of only very limited Pleistocene glaciation north of the Tara canyon, even on mountains as high as Ljubišnja (2238 m a.s.l.).

The ELAs calculated for the different glaciations are relative to modern sea level. However, tectonic activity and sea level changes would have been very important in this region. At the height of the last glaciation, during the Tymphian Stage (MIS 2), eustatic sealevels were $120 \mathrm{~m}$ lower and large areas of the Adriatic basin were exposed as land, especially in the north (van Andel and Shackleton, 1982; Correggiari et al., 1996). Lower eustatic sea-levels during glacial stages implies that ELAs would have been higher than those reconstructed using modern sea-levels. This is counter to the effects of uplift which result in real ELAs being lower than those reconstructed in the modern environment. In Greece, Hughes 


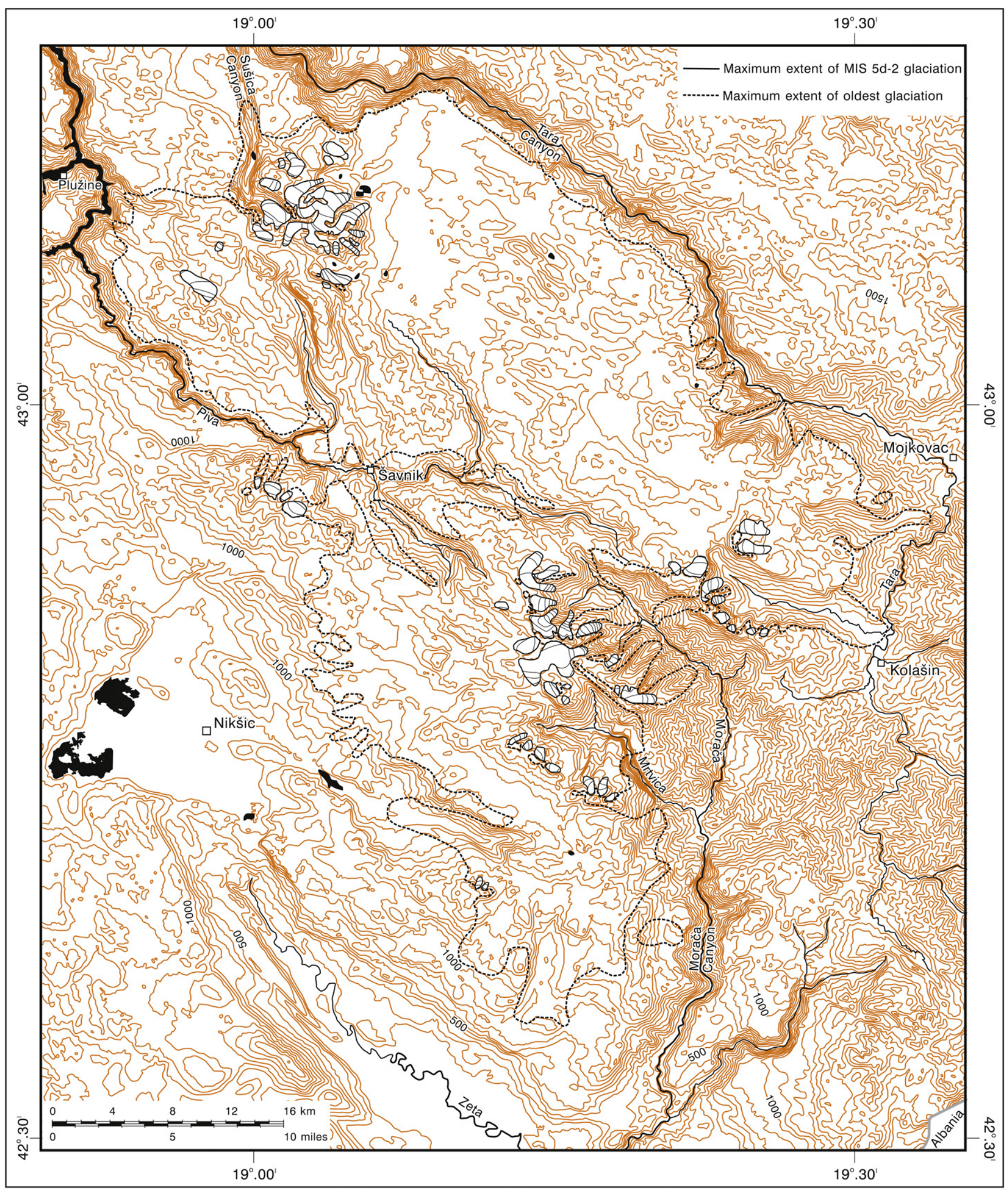

Fig. 10. Ice field and glacier reconstruction for the maximum extent of glaciation during the last glacial cycle. This occurred sometime before $13.4 \pm 0.4 \mathrm{ka}$ in the Durmitor massif. Smaller glaciers also existed during the Younger Dryas and one small glacier survives today in the Durmitor massif. 
(2004, p. 226) calculated that reconstructed ELAs for the last glacial cycle were c. $100 \mathrm{~m}$ lower than the 'real' ELAs because of the interplay of eustatic sea-levels and uplift. In contrast, for the largest Middle Pleistocene glaciation (MIS 12) reconstructed ELAs may overestimate 'real' ELAs by $60-240 \mathrm{~m}$. However, providing accurate corrections for Pleistocene ELAs taking into account uplift and sea level change in the Balkans is difficult because of the locallycomplex tectonics of this area. For example, most of Montenegro is currently experiencing uplift (up to $4 \mathrm{~mm}$ per year in some places) although exceptions include the area around the Boka Kotorska near Mount Orjen which is undergoing subsidence (Djurović and Petrović, 2007). To compound the problem of estimating Pleistocene uplift rates there is the problem of subsidence caused by isostatic loading by the large ice masses themselves. Due to this complexity, no corrections to ELAs are attempted in this paper.

In common with the records from Greece, throughout Montenegro, Late Pleistocene glaciers were much smaller than Middle Pleistocene glaciers and this must be related to either warmer summer temperatures or drier winter conditions. For the Pindus Mountains of northern Greece and the coastal mountains of Montenegro, Hughes et al. (2007, 2010) have argued that the glacier maxima of the last cold stage (MIS $5 \mathrm{~d}-2$ ) were associated with higher summer temperatures than during the equivalent phase of MIS 12. If the reverse were true (i.e. colder last cold stage compared with the largest Middle Pleistocene glaciation, MIS 12), then conditions must have been much wetter during MIS 12 to produce such large and lower altitude ice masses. However, the long pollen record from Tenaghi Philippon in northern Greece suggests otherwise, with MIS 12 being characterised by severe moisture stress with the lowest frequencies of arboreal pollen in the last $450 \mathrm{ka}$ (Tzedakis et al., 2003; Tzedakis, 2005). Thus, if the most extensive glaciation does correlate with MIS 12, then conditions at this time must have been significantly colder than during the equivalent event of the last cold stage.

The Žabljak Member moraines appear to represent a complex of different-aged moraines that cannot be differentiated solely on the basis of soil weathering characteristics. The moraines west of Žabljak yielded calcites that date from MIS 5 (105.4 \pm 6.4 and $120.2 \pm 6.2 \mathrm{ka}$ ). These ages are consistent with calcite formation during the interglacial immediately after the formation of the moraines during the penultimate glacial cycle - named the Vlasian Stage in Greece (MIS 6) - and this is in good agreement with the records from both Orjen in western Montenegro (Hughes et al., 2010) and the Pindus of northwestern Greece (Hughes et al., 2006a,b). However, the nearby Junčev do moraine on the southern edge of Žabljak town contains a range of older and younger calcite cements, the oldest dating from MIS $7(231.9 \pm 17.5 \mathrm{ka})$ with other calcites dating from MIS $6(162.7 \pm 7.9 \mathrm{ka})$ and MIS $4(58.8 \pm 2.0 \mathrm{ka})$. The wide range of ages at this site is interpreted as being the result of either prolonged percolation of spring waters through the moraine or intermittent reactivation of spring waters at the same locality during MIS 7, 6 and 4. The oldest calcites in the Junčev do moraine are very significant because these moraines are a long way ( $>5 \mathrm{~km}$ ) up-valley of the lowest Ninkovići Member moraines. The soil on the Junčev do moraine has the same weathering characteristics as other moraines in the Žabljak area that contain younger calcites (that are no older than the Last Interglacial). Thus, as noted in the results section, this causes problems when attempting to subdivide moraines. In the case of the moraines ascribed to the Žabljak Member, the available evidence favours the idea of a palimpsest of closely-spaced moraines but widely separated in age. In this scenario the Junčev do moraines could have formed between MIS 12 and 6, possibly during MIS 8 or 10 . The limiting age of $231.9 \pm 17.5 \mathrm{ka}$ suggests MIS 8 , but more ages are needed to confirm this.
At the Tenaghi Philippon long lacustrine site in northern Greece, the most extreme arboreal pollen minima are encountered during the glacial maximum of MIS 12, followed in order of decreasing extremity by those of MIS 6, MIS 2, MIS 10 and finally MIS 8 (Tzedakis et al., 2003; Tzedakis, 2005). If arboreal pollen frequencies are taken to be representative of moisture supply then this would mean MIS 12 was the driest and MIS 8 the wettest. Given the importance of both precipitation (winter) and temperatures (summer) in glacier mass balance (Hughes and Braithwaite, 2008), then it is entirely plausible that glaciers could have extended down to Junčev do during MIS 8. There is also evidence of cold and wet conditions during MIS 6 (Roucoux et al., 2011) which may have produced similar-sized glaciers to MIS 8. In this situation the MIS 6 glaciers could have overridden and eroded earlier MIS 8 moraines. It may be the case that MIS 6 glaciers were larger than MIS 8 glaciers in some localities but not in others resulting in a complicated record of MIS 8 and MIS 6 glaciations in different valleys. It is apparent from central Montenegro that the glacier history for the period MIS 10-6 is more complex than that recorded on the coastal mountains at Orjen (Hughes et al., 2010) and in the mountains of northwest Greece (Hughes et al., 2006a). Further detailed work on the nature of MIS 8 (and 10), like the Ioannina pollen record recently completed for MIS 6 by Roucoux et al. (2011), will help constrain the climatic combinations and associated glacier advances during these glacial cycles. Moreover, a more precise geochronology for glacial events is also needed in order to tie the glacial and long pollen (and other) records together.

The peninsulas of southern Europe are known to have been important areas of refugia for plants and animals during cold stages (Bennett et al., 1991; Tzedakis, 1993; Hewitt, 2000, 2004). Mountainous areas of these peninsulas, in particular, are thought to have been important refugia because of sustained moisture supply when conditions were during cold and arid in the lowlands (Tzedakis, 1993). The effects of the major ice sheets of the Alps and northern Europe in driving biotic change and the role of the Mediterranean peninsulas in providing cold stage refugia has received considerable attention in the last decade, especially since the papers of Hewitt (2000, 2004). However, it is becoming clear that ice cover was very extensive even over the mountains of these peninsulas as is illustrated in the Balkans on Orjen and also in other peninsulas such as Iberia (Cowton et al., 2009). Whilst the presence of extensive ice masses would have rendered large parts of the Mediterranean mountains unsuitable for thermophilous species, which would have been restricted to low-altitude refugia, the mountains would have provided important refugia for cold-adapted species (Nève and Verlaque, 2009). As noted above, the strongest contender for the largest glaciation is MIS 12. This interval has been identified by Tzedakis (2005) as one of most severe of the last million years in the Balkans and Gamble (1999) identified this cold stage as a pivotal event in the evolution of early humans (Neanderthals). It is likely, therefore, that glaciers exerted considerable influence not only on geomorphological evolution of the Balkans (e.g. Woodward et al., 2008) but also on biological evolution too.

Given that the authors have found evidence of large glaciations in numerous other parts of southeastern Montenegro not covered in this paper, such as the Bieljasica, Komovi, Kuči (Fig. 1) and Prokletije massifs, amongst others, the total glaciated area of Montenegro is likely to be much greater. Little is known about former glacier extent in Bosnia, although it is clear that the mountains are extensively glaciated on the border mountains of Volujak, Bioč and Maglić (Milivojević, 2004b). Further north in Croatia there is stratigraphical evidence that glaciers from a very large ice cap reached the coast of Dalmatia during the Middle Pleistocene (Marjanac and Marjanac, 2004) and work is in progress in this area in order to establish the extent and timing of glaciations. 
Across the Mediterranean mountains there appears to be major differences in the timings of glaciations. Understanding these differences and what they mean for understanding cold stage palaeoclimate in the Mediterranean basin is one of the most pressing challenges for glacial research in this region and beyond (Hughes and Woodward, 2008; Thackray et al., 2008; Woodward and Hughes, 2011). Robust geochronologies accompanied by glaciological modelling of the former glaciers and their associated climates is crucial in order for the glacier records to be compared and integrated with other records of long-term environmental change in the Mediterranean (cf. Tzedakis, 2007; Woodward, 2009).

\section{Conclusions}

Ice caps once covered large areas of the uplands in the Balkans. The largest ice cap in Montenegro covered an area of nearly $1500 \mathrm{~km}^{2}$. This included the Durmitor, Sinjajevina, Moračke, Maganik and Prekornica massifs across the centre of the country, whilst valley glaciers formed on satellite mountains such as Vojnik. More than $30 \mathrm{U}$-series dates from secondary carbonates cementing tills across Montenegro (including Orjen on the coast) provide a geochronological framework for the glacial stratigraphy. Six ages indicate that the most extensive glaciation occurred before $350 \mathrm{ka}$ during the Middle Pleistocene, possibly correlating with a major phase of glaciation in elsewhere in Europe during MIS 12 (c. 470-420 ka). Later, less extensive, glaciations occurred during MIS 10-6 (360-130 ka) and at least two different glacial advances appear to be represented by closely-spaced moraines, with one correlating with MIS 6 and the other tentatively with MIS 8. Ice fields and valley glaciers formed during the last cold stage (MIS 5d-2) but were much smaller than the earlier glaciations. Cirque and valley glaciers were also present during the Younger Dryas (12.9-11.7 ka), whilst the most recent Holocene glaciers formed just a short distance upvalley. The magnitude of Middle Pleistocene glaciation in Montenegro hints at extensive glaciation in nearby countries in the western Balkans, such as Albania, Bosnia-Herzegovina and Croatia. The Dinaric Alps represented one of the largest centres of ice accumulation during the Middle Pleistocene in Europe. Whilst much smaller in size than the ice masses of Fennoscandinavia, BritainIreland and the Alps, the Balkan ice caps are likely to have rivalled in size the ice masses over the Pyrenees and were certainly amongst the largest ice masses of the Mediterranean mountains.

\section{Acknowledgements}

This research was supported by a Peter Fleming Award from the Royal Geographical Society (with IBG) awarded to Philip Hughes. The U-series dating was supported by the UK Natural Environment Research Council award (IP/878/1105) to Hughes and Woodward. All of the figures were drawn by Graham Bowden in the Cartographic Unit in the School of Environment and Development at The University of Manchester. We would like to thank the two anonymous referees for their very helpful comments and recommendations.

\section{References}

Akçar, N., Yavuz, V., Ivy-Ochs, S., Kubik, P.W., Vardar, M., Schlüchter, C., 2007. Paleoglacial records from Kavron Valley, NE Turkey: field and cosmogenic exposure dating evidence. Quaternary International 164-165, 170-183.

Akçar, N., Yavuz, V., Ivy-Ochs, S., Kubik, P.W., Vardar, M., Schlüchter, C., 2008. A case for a down wasting mountain glacier during Termination I, Verçenik Valley, NE Turkey. Journal of Quaternary Science 23, 273-285.

Benn, D.I., Hulton, N.R.J., 2010. An Excel ${ }^{\mathrm{TM}}$ spreadsheet program for reconstructing the surface profile of former mountain glaciers and ice caps. Computers and Geosciences 36, 605-610.

Bennett, K.D., Tzedakis, P.C., Willis, K.J., 1991. Quaternary refugia of north European trees. Journal of Biogeography 18, 103-115.
Birkeland, P.W., 1999. Soils and Geomorphology, third ed. Oxford University Press, New York.

Bognar, A., Prugovečki, I., 1997. Glaciation traces in the area of the Risnjak mountain Massif. Geologica Croatica 50 (2), 269-278.

Bošković, M., Bajković, I., 2004. Waters of Montenegro. BALWOIS: Water Observation and Information System for Balkan Countries. Paper number: A-403. Available at: http://balwois.com/balwois/administration/full_paper/ffp-870.pdf (accessed 28.07.11.).

van Calsteren, P., Schwieters, J.B., 1995. Performance of a thermal ionisation mass spectrometer with a deceleration lens system and post-deceleration detector selection. International Journal of Mass Spectrometry and Ion Processes 146 (147), 119-129.

Correggiari, A., Roveri, M., Trincardi, F., 1996. Late Pleistocene and Holocene evolution of the north Adriatic Sea. Quaternario 9, 697-704.

Cowton, T., Hughes, P.D., Gibbard, P.L., 2009. Palaeoglaciation of Parque Natural Lago de Sanabria, northwest Spain. Geomorphology 108, 282-291.

Ćurić, M., 1996. Climate of Durmitor national park. In: Lješević, M. (Ed.), The Nature of National Park Durmitor, vol. 8. Faculty of Geographie, University of Belgrade, pp. 151-162. Special Editions.

Cvijić, J., 1889. In: Glacijalne i morfološke studije o planinama Bosne, Hercegovine i Crne Gore, vol. LVII 1/21. Glas Srpske Kraljevske Akademije Nauka, Beograd.

Cvijić, J., 1903a. In: Novi rezultati o glacijalnoj eposi Balkanskog poluostrva, vol. LXV 1/25. Glas Srpske Kraljevske Akademije Nauka, Beograd.

Cvijić, J., 1903b. In: Balkanska, alpska i karpatska glacijacija, vol. 67. Glas Srpske Kraljevske Akademije Nauka, Beograd.

Cvijić, J., 1913. In: Ledeno doba u Prokletijama i okolnim planinama, vol. XCI. Glas Srpske Kraljevske Akademije Nauka, Beograd, pp. 1-149.

Cvijić, J., 1914. Eiszeitliche Vergletscherung der Gebirgsgruppen von Prokletije bis Durmitor. Maßstab 1:200,000. K.u.k. Militärgeographischen Institutes, Wien.

Cvijić, J., 1917. L'époque glaciaire dans la péninsule des Balkanique. Annales de Géographie 26, 189-218.

Dehnert, A., Preusser, F., Kramers, J.D., Akçar, N., Kubik, P., Reber, R., Schlüchter, C., 2010. A multi-dating approach applied to proglacial sediments attributed to the most extensive glaciation of the Swiss Alps. Boreas 39, 620-632.

Djurović, P., 2009. Reconstruction of the Pleistocene glaciers of Mt. Durmitor in Montenegro. Acta Geographica Slovenica 49 (2), 263-289.

Djurović, P., Petrović, A., 2007. Large canyons in Dinaric and Prokletije mountain regions of Montenegro. Geographica Pannonica 11, 14-18.

Edwards, R.L., Chen, H., Wasserburg, G.J., 1987. ${ }^{238} \mathrm{U}-{ }^{234} \mathrm{U}-{ }^{230} \mathrm{Th}-{ }^{232} \mathrm{Th}$ systematics and the precise measurement of time over the past 500,000 years. Earth and Planetary Science Letters 81, 175-192.

Fairchild, I.J., Bradby, L., Spiro, B., 1994. Reactive carbonate in glacial systems: a preliminary synthesis of its creation, dissolution and reincarnation. In: Deynoux, M., Miller, J.M.G., Domack, E.W., Eyles, N., Fairchild, I.J., Young, G.M. (Eds.) Earth's Glacial Record. International Geological Correlation Project 260. Cambridge University Press, pp. 176-192.

Gamble, C.S., 1999. The Palaeolithic Societies of Europe. Cambridge University Press, Cambridge, p. 505

Grunewald, K., Scheithauer, J., 2010. Europe's southernmost glaciers: response and adaptation to climate change. Journal of Glaciology 56, 129-142.

Harden, J.W., 1982. A quantitative index of soil development from field descriptions: examples from a chronosequence in central California. Geoderma 28, 1-28.

Hewitt, G.M., 2000. The genetic legacy of the Quaternary ice ages. Nature 405, 907-913.

Hewitt, G.M., 2004. Genetic consequences of climatic oscillations in the Quaternary. Philosophical Transactions of the Royal Society, London B359, 183-195.

Hughes, P.D., 2004. Quaternary Glaciation in the Pindus Mountains, Northwest Greece. PhD Thesis. Darwin College, University of Cambridge. Available at: https://www.escholar.manchester.ac.uk/uk-ac-man-scw:16975 p. 341.

Hughes, P.D., 2007. Recent behaviour of the Debeli Namet glacier, Durmitor, Montenegro. Earth Surface Processes and Landforms 10, 1593-1602.

Hughes, P.D., 2008. Response of a Montenegro glacier to extreme summer heatwaves in 2003 and 2007. Geografiska Annaler 90A, 259-267.

Hughes, P.D., 2009. Twenty-first century glaciers in the Prokletije mountains, Albania. Arctic, Antarctic and Alpine Research 41, 455-459.

Hughes, P.D., 2010a. The role of geomorphology in Quaternary stratigraphy: morphostratigraphy, lithostratigraphy and allostratigraphy. Geomorphology 123, 189-199.

Hughes, P.D., 2010b. Little Ice Age glaciers in Balkans: low altitude glaciation enabled by cooler temperatures and local topoclimatic controls. Earth Surface Processes and Landforms 35, 229-241.

Hughes, P.D., Braithwaite, R.J., 2008. Application of a degree-day model to reconstruct Pleistocene glacial climates. Quaternary Research 69, 110-116.

Hughes, P.D., Woodward, J.C., 2008. Timing of glaciation in the Mediterranean mountains during the last cold stage. Journal of Quaternary Science 23, 575-588.

Hughes, P.D., Woodward, J.C., 2009. Glacial and Periglacial environments. In: Woodward, J.C. (Ed.), The Physical Geography of the Mediterranean. Oxford University Press, Oxford, pp. 353-383.

Hughes, P.D., Woodward, J.C., Gibbard, P.L., Macklin, M.G., Gilmour, M.A., Smith, G.R., 2006a. The glacial history of the Pindus mountains, Greece. Journal of Geology $114,413-434$.

Hughes, P.D., Woodward, J.C., Gibbard, P.L., 2006b. The last glaciers of Greece. Zeitschrift für Geomorphologie 50, 37-61. 
Hughes, P.D., Woodward, J.C., Gibbard, P.L., 2007. Middle Pleistocene cold stage climates in the Mediterranean: new evidence from the glacial record. Earth and Planetary Science Letters 253, 50-56.

Hughes, P.D., Woodward, J.C., van Calsteren, P.C., Thomas, L.E., Adamson, K., 2010. Pleistocene ice caps on the coastal mountains of the Adriatic Sea: palaeoclimatic and wider palaeoenvironmental implications. Quaternary Science Reviews 29, 3690-3708.

Kern, Z., Surányi, G., Molnár, M., Nagy, B., Balogh, D., 2007. Investigation of natural perennial ice deposits of Durmitor mts, Montenegro. In: Proceedings of the 2nd International Workshop on Ice Caves Demänská Dolina, Slovak Republic, May 8th-12th, 2006

Kotarba, A., Hercman, H., Dramis, F., 2001. On the age of Campo Imperatore glaciations, Gran Sasso Massif, Central Italy. Geografia Fisica e Dinamica Quaternaria 24, 65-69.

Kuhlemann, J., Milivojević, M., Krumrei, I., Kubik, P.W., 2009. Last glaciation of the Šara range (Balkan peninsula): increasing dryness from the LGM to the Holocene. Austrian Journal of Earth Sciences 102, 146-158.

Lazić, L., Tošić, I., 1998. A real data simulation of the Adriatic Bora and the impact of Mountain height on Bora Trajectories. Meteorology and Atmospheric Physics $66,143-155$.

Liedtke, H., 1962. Eisrand und Karstpoljen am Westrand Lukavica-Hochfläche. Erdkunde XVI, 289-298.

Magaš, D., 2002. Natural-geographic characteristics of the Boka Kotorska area as the basis of development. Geoadria 7 (1), 51-81.

Marjanac, L., Marjanac, T., 2004. Glacial history of the Croatian Adriatic and coastal Dinarides. In: Ehlers, J., Gibbard, P.L. (Eds.), Quaternary Glaciations - Extent and Chronology. Part I: Europe. Elsevier, Amsterdam, pp. 19-26.

Marjanac, T., Marjanac, L., Oreški, E., 1990. Glacijalni I periglacijalni sedimenti u Novigradskom moru. Geologica vjesnik 43, 35-42.

Marović, M., Marković, M., 1972. Glacijalna morfologija šire oblasti Durmitora. Geološki anali Balkanskog poluostrva 37, 37-48.

Menković, L., Marković, M., Cupković, T., Pavlović, R., Trivić, B., Banjac, N., 2004. Glacial morphology of Serbia (Yugoslavia), with comments on the Pleistocene glaciation of Montenegro, Macedonia and Albania. In: Ehlers, J., Gibbard, P.L. (Eds.), Quaternary Glaciations-Extent and Chronology. Part I: Europe. Elsevier, Amsterdam, pp. 379-384.

Messerli, B., 1967. Die eiszeitliche und die gegenwartige Vertgletscherung im Mittelemeeraum. Geographica Helvetica 22, 105-228.

Milivojević, M., Menković, L., Ćalić, J., 2008. Pleistocene glacial relief of the central part of Mt. Prokletije (Albanian Alps). Quaternary International 190, 112-122.

Milivojević, M., 2004a. Glacial morphology of Komovi. Glasnik Srpskog geografskog društva 84, 45-60.

Milivojević, M., 2004b. The Glacial Relief on Mt Volujak with Mt Bioč and Mt Maglić, vol. 68. Geographic Institute "Jovan Cvijić" Serbian Academy of Science and Arts. Special Issues 130 .

Milojević, B.Ž., 1937. Visoke planine u našoj Kraljevini. Državna štamparija Kraljevine Jugoslavije, Beograd.

Milojević, B.Ž., 1950a. O kanjonskoj dolini durmitorske Komarnice. Glas Srpske Kraljevske Akademije Nauka 196 (2) (Beograd).

Milojević, B.Ž., 1950b. O kanjonskoj dolini durmitorske Sušice. Radovi Zavoda Jugoslavenske akademije znanosti i umjetnosti u Zadru 280 (Zagreb).

Milojević, B.Ž., 1951. Durmitor - regionalno-geografska istraživanja. Zbornik radova - Srpska akademija nauka 9 (2) (Beograd).

Mirković, M., Vujisić, P., 1989. Osnovna geološka karta Jugoslavije, Scale 1:100,000, Žabljak, Sheet K34-27. Savezni geološki zavod, Beograd.

Nève, G., Verlaque, R., 2009. Genetic differentiation between and among refugia. In: Habel, J.C., Assman, T. (Eds.), Relict species: Phylogeography and Conservation Biology. Springer-Verlag, Berlin Heidelberg, pp. 277-294.

$\mathrm{Ng}$, F.S.L., Barr, I.D., Clark, C.D., 2010. Using the surface profiles of modern ice masses to inform palaeo-glacier reconstructions. Quaternary Science Reviews 29, 3240-3255.

Nicod, J., 1968. Premières recherches de morphologie karstique dans le massif du Durmitor (Crna Gora:Montenegro). Meditérraneé 3, 187-216.

Nye, J.F., 1952. A method for calculating the thickness of ice sheets. Nature 169, 529-530.

Osmaston, H., 2002. The nature, extents and climates of former Quaternary tropical glaciers, with reference to the East African Mountains. In: Kaser, G.,
Osmaston, H. (Eds.), Tropical Glaciers. Cambridge University Press, Cambridge, pp. 149-192.

Osnovna Geološka Karta SFRJ, 1970. Šavnik, Sheet K34-39, Scale 1:100,000. Saveznog geološkog zavoda, Beograd.

Osnovna Geološka Karta SFRJ, 1971. Titograd, Sheet K34-51, Scale 1:100,000. Saveznog geološkog zavoda, Beograd.

Porter, S.C., 1975. Equilibrium-line altitudes of late Quaternary glaciers in the Southern Alps, New Zealand. Quaternary Research 5, 27-47.

Roucoux, K.H., Tzedakis, P.C., Lawson, I.T., Margari, V., 2011. Vegetation history of the penultimate glacial period (Marine Isotope Stage 6) at Ioannina, north-west Greece. Journal of Quaternary Science. doi:10.1002/jqs.1483.

Sarıkaya, M.A., Zreda, M., Çiner, A., Zweck, C., 2008. Cold and wet Last Glacial Maximum on Mount Sandiras, SW Turkey, inferred from cosmogenic dating and glacier modelling. Quaternary Science Reviews 27, 769-780.

Sarıkaya, M.A., Zreda, M., Çiner, A., 2009. Glaciations and paleoclimate of Mount Erciyes, central Turkey, since the Last Glacial Maximum, inferred from ${ }^{36} \mathrm{Cl}$ dating and glacier modeling. Quaternary Science Reviews 23-24, 2326-2341.

Schilling, D.H., Hollin, J.T., 1981. Numerical reconstructions of valley glaciers and small ice caps. In: Denton, G.H., Hughes, T.J. (Eds.), The Last Great Ice Sheets. Wiley, New York, pp. 207-220.

Smith, G.W., Nance, R.D., Genes, A.N., 1997. Quaternary glacial history of Mount Olympus. Geological Society of America Bulletin 109, 809-824.

Smith, G.W., Nance, R.D., Genes, A.N., 2006. Pleistocene glacial history of Mount Olympus, Greece: Neotectonic uplift, equilibrium line elevations, and implications for climatic change. In: Dilek, Y., Pavlides, S. (Eds.), Postcollisional tectonics and magmatism in the Mediterranean region and Asia. Geological Society of America Special Paper 409, pp. 157-174.

Thackray, G.D., Owen, L.A., Yi, C., 2008. Timing and nature of late Quaternary mountain glaciaation. Journal of Quaternary Science 23, 503-508.

Tzedakis, P.C., 1993. Long-term tree populations in northwest Greece through multiple Quaternary climatic cycles. Nature 364, 437-440.

Tzedakis, P.C., 2005. Towards an understanding of the response of southern European vegetation to orbital and suborbital climate variability. Quaternary Science Reviews 24, 1585-1599.

Tzedakis, P.C., 2007. Seven ambiguities in the Mediterranean palaeoenvironmental narrative. Quaternary Science Reviews 26, 2042-2066.

Tzedakis, P.C., McManus, J.F., Hooghiemstra, H., Oppo, D.W., Wijmstra, T.A., 2003. Comparison of changes in vegetation in northeast Greece with records of climate variability on orbital and suborbital frequencies over the last 450,000 years. Earth and Planetary Science Letters 212, 197-212.

van Andel, T.H., Shackleton, J.C., 1982. Late Paleolithic and mesolithic coastlines of Greece and the Aegean. Journal of Field Archaeology 9, 445-454.

Velić, J., Velić, I., Kljajo, D., 2011. Sedimetary bodies, forms and occurrences in the Tudorevo and Mirovo glacial deposits of northern velebit. Geologica Croatica 64 (1), 1-16.

Veselinović, D., Kovačević, D., Rajšić, S., Vurkmirović, Z., Djordjević, D., Stanković, S., Stanković, A., 2001. The metal amounts in ce stalagmite of "ice cave" snow and water at Durmitor mountains (Yugoslavia). Journal of Environmental Protection and Ecology 2, 34-36.

Woodward, J.C. (Ed.), 2009. The Physical Geography of the Mediterranean. Oxford University Press, p. 704.

Woodward, J.C., Hughes, P.D., 2011. Glaciation in Greece: a new record of cold stage environments in the Mediterranean. In: Ehlers, J., Gibbard, P.L., Hughes, P.D. (Eds.), Quaternary Glaciations - Extent and Chronology: A Closer Look. Elsevier, Amsterdam, pp. 175-198.

Woodward, J.C., Macklin, M.G., Smith, G.R., 2004. Pleistocene glaciation in the mountains of Greece. In: Ehlers, J., Gibbard, P.L. (Eds.), Quaternary Glaciations Extent and Chronology: Part 1. Elsevier, Amsterdam, pp. 155-173.

Woodward, J.C., Hamlin, R.H.B., Macklin, M.G., Hughes, P.D., Lewin, J., 2008. Glacial activity and catchment dynamics in northwest Greece: long-term river behaviour and the slackwater sediment record for the last glacial to interglacial transition. Geomorphology 101, 44-67.

Zahno, C., Akçar, N., Yavuz, V., Kubik, P., Schlüchter, C., 2009. Surface exposure dating of late Pleistocene glaciations at the Degegöl mountains (Lake Beyşehir SW Turkey). Journal of Quaternary Science 24, 1016-1028.

Živaljević, M., Vujisić, P., Mirković, M., Đokić, V., Čepić, M., 1981. Osnovna geološka karta SFRJ, Ivangrad, Sheet K34-40, Scale 1:100,000. Savezni geološki zavod, Beograd. 